\title{
The Impact of Weaning Stress on Gut Health and the Mechanistic Aspects of Several Feed Additives Contributing to Improved Gut Health Function in Weanling Piglets-A Review
}

\author{
Santi-Devi Upadhaya (D) and In-Ho Kim * \\ Department of Animal Resource and Science, Dankook University, No.29 Anseodong, Cheonan 31116, \\ Choongnam, Korea; santi.upadhaya@gmail.com \\ * Correspondence: inhokim@dankook.ac.kr; Tel.: +82-41-550-3652; Fax: +82-41-565-2949
}

check for updates

Citation: Upadhaya, S.-D.; Kim, I.-H. The Impact of Weaning Stress on Gut Health and the Mechanistic Aspects of Several Feed Additives

Contributing to Improved Gut Health Function in Weanling Piglets-A

Review. Animals 2021, 11, 2418.

https://doi.org/10.3390/ani11082418

Academic Editor: José

Francisco Pérez

Received: 19 July 2021

Accepted: 9 August 2021

Published: 17 August 2021

Publisher's Note: MDPI stays neutral with regard to jurisdictional claims in published maps and institutional affiliations.

Copyright: (c) 2021 by the authors. Licensee MDPI, Basel, Switzerland. This article is an open access article distributed under the terms and conditions of the Creative Commons Attribution (CC BY) license (https:/ / creativecommons.org/licenses/by/ $4.0 /)$.
Simple Summary: The current review aimed to provide an overview on the problems associated with weaning with a special focus on gut health, and also highlighted the nutritional approach using different kinds of feed additives and their mechanistic aspects in mitigating production inefficiencies and gut health dysfunction in weanling pigs.

Abstract: Newly weaned pig encounters psychosocial, physical, and nutritional stressors simultaneously when their immune system is not fully developed. These stressors have a cumulative effect on the immune response that contributes to the post-weaning growth lag which is characterized by depression in feed intake, reduced or negative growth rates, and increased susceptibility to pathogens in the first 24 to $48 \mathrm{~h}$ post-weaning. Consequently, the intestinal integrity, and digestive and absorptive capacity are impaired, and there is an increase in intestinal oxidative stress. It also causes the shifts in the taxonomic and functional properties of intestinal microbiome abruptly, thereby adversely affecting the health and performance of animals. It has been suggested that the effects of weaning stress on immune functions, intestinal barrier functions, and nervous system function in early weaned pigs extends into adulthood. The inclusion of different types of feed additives into the diet have been reported to alleviate the negative effects of weaning stress. The objective of this paper was to provide an overview on how the weaning stress affects gut health and the impact it has on production efficiencies, as well as the mechanistic aspects of several feed additives applied in reducing the weaning associated gut health problems and performance inefficiencies.

Keywords: gut health; mechanistic aspect; nutritional intervention; piglet; weaning stress

\section{Introduction}

In pigs' lives, weaning is a rather challenging and stressful event that leads to enormous changes in the piglet's gastrointestinal tract, resulting in the perturbations in gut microbiota, host physiology, and mucosal immune function [1] with subsequent reduction in feed intake, occurrence of post-weaning diarrhea, and growth reduction [2,3]. The mucosa epithelial cells are the largest immune organ in pigs and are the first responders to microorganisms in the gut. The health of the mucosa epithelium, the cells that line the gastrointestinal tract, plays a pivotal role on the growth and development of the pig through secretion and absorption. The intestinal mucosa is susceptible to inflammation since it is constantly exposed to the luminal environment including bacteria, toxins, and pathogens [4]. With the ban in the use of in-feed antibiotics due to rising public concerns of resultant antibiotic-resistant pathogens in both livestock and humans, the swine industry faces challenges of keeping pigs healthy, especially at post-weaning. Thus, the characteristic features of a healthy gut may include, but are not limited to, a healthy proliferation of epithelial cells lining the intestinal wall, proper gut barrier function, a beneficial and 
balanced gut microbiota, and a well-developed intestinal mucosa immunity [5]. Therefore, weaning pig requires adequate and high-quality nutrients, and proper husbandry and management practices, which are emphasized primarily towards rapid feed intake encouragement whilst reducing mortality and morbidity. Thus, to overcome the weaning transition problems, pre-weaning and post-weaning strategies are employed. Pre-weaning nutritional strategies aim to give piglets a stronger start before they encounter major stressors by supplementing creep feed [6]. However, post-weaning nutritional strategies aid piglet recovery post-weaning. This review is focused on describing post-weaning associated gut health issues and their impact on production efficiencies, as well as highlighting the effect of some selected feed additives in mitigating these problems.

\section{Impact of Weaning Stress in Young Pigs}

\subsection{Gut Health and Intestinal Barrier}

The gastrointestinal tract (GIT) is a very dynamic organ and is not only limited to digestion and absorption of nutrients but also maintains fluid balance, thereby achieving the required viscosity of luminal contents. It also secretes digestive enzymes, mucins, and immunoglobulins, and maintains barrier function against harmful pathogens and antigens $[7,8]$. The functioning of the GIT is highly influenced by a complex interaction between nutrition, the intestinal mucosal membrane, and the indigenous microflora which affect the entire physiology, health, and well-being of an animal [9]. Weaning transition leads to physiological change in structural and functional aspects of the intestine, leading to the atrophy of villous and increased crypt depth. These physiological changes can adversely affect digestion, absorption, secretion, and maintenance of barrier function, which may consequently lead to deprivation in feed intake, thereby reducing the growth performance of post weaning pigs [10-12]. For instance, Hampson [13] noted a reduction of villus height by 25 to $35 \%$ pre-weaning within $24 \mathrm{~h}$ in pigs that were weaned at 21 days of age, and the reduction in villous height continued for 5 days after weaning resulting in half of the initial height. Thus, for maximizing pig production, it is necessary to reduce physiological changes in the small intestine as much as possible during the weaning transition.

A single layer of columnar epithelial cells lining the intestinal tract functions as intestinal barrier. These cells are sealed by junctional complexes, including tight and adherens junctions, in close proximity to the apical and lateral sides of the paracellular space [7] and they provide the first line of defense against pathogenic microorganisms and antigens that are present within the intestinal lumen. The breakdown of the intestinal barrier results in increased intestinal permeability allowing the pathogenic agents present in luminal contents to leak across the epithelium, making it easy to access the sub-epithelial tissue [14,15]. This leakage consequently leads to inflammation, diarrhea, malabsorption, and systemic disease that can eventually influence animal health and growth status $[8,16]$. In several post-weaning swine enteric diseases, functional impairment of intestine has been shown to be the most important pathophysiological event. In a study, Moeser et al. [17] evaluated the intestinal dysfunction in pigs weaned at 19 days of age and found that weaned pigs had higher intestinal permeability and enhanced secretory activity in the jejunum and colon than in unweaned pigs which corroborated with the findings of Boudry et al. [10] who demonstrated a transient reduction in transepithelial resistance in jejunum. However, with the increase in the weaning age of the animal, there were improvements in intestinal barrier function as indicated by improved transient reduction in transepithelial resistance as well as reduction in mucosal-to-serosal flux of paracellular probes mannitol and inulin [18]. Earlier studies $[19,20]$ suggest that disturbances in GI barrier functions and the immune and nervous system functions in early weaned pigs persist into adulthood. These findings suggest that weaning age can have an impact on the intestinal barrier function $[17,18]$ and consideration should be taken to wean at an appropriate age for the healthy production of wean-finished pigs. Alleviating intestinal dysfunction during this process is important, given the direct relationship between animal health and economic productivity. Preserving intestinal health minimizes the adverse effects of weaning-induced stress. 


\subsection{Weaning Transition and Gut Microbiota}

A dynamic composition of microbiota inhabits the GIT of pig which shifts over with time as well as along the different segments of GIT. Microbial colonization starts right from the time of birth and is shaped by the consumption of dam's milk resulting in milkoriented microbiome [21,22]. Weaning of pigs is done during weeks $3-4$ in the modern swine industry, and pigs are fed solid diets [1]. This weaning transition is characterized by a shift in the microbial population where pathogenic bacteria increase in numbers [23]. The unhealthy alterations in gut microbiota composition triggered by weaning stress may be one of the major reasons for post-weaning diarrhea. It was revealed from a recent metagenomic analysis of the fecal microbiota that diarrhea was associated with increase in the relative abundance of Prevotella, Sutterella, Campylobacter, and Fusobacteriaceae [24].

Li et al. [1] showed remarkable differences in microbiome between nursing and weaning piglets. For instance, a reduction in Alloprevotella and Oscillospira whereas an increment in Campylobacterales, Campylobacteraceae and Campylobacter microbial population were observed in weaned piglets. It has been suggested that Alloprevotella mainly produce succinate and acetate, which plays a role in improving the gut barrier and exhibit anti-inflammatory function [25]. Oscillospira species are butyrate producers, and they can reduce the inflammatory disease condition [26,27]. The increase in Campylobacteraceae and Campylobacter after weaning indicates a life-threatening GIT disease [28]. In agreement with previous studies of Kim et al. [29] and Hu et al. [30], Li et al. [1] demonstrated that Bacteroidetes and Firmicutes were the two most dominant phyla in the intestine of piglets followed by Proteobacteria and Fusobacteria, regardless of weaning. However, in other studies, the relative abundances of microorganisms belonging to family Bacteroidaceae and Enterobacteriaceae declined over time, while there was a rise in the population of Lactobacillaceae, Ruminococcaceae, Veillonellaceae, and Prevotellaceae families in weaned piglets [31-33].

To deal with the stresses caused by dietary change during weaning transition, orientation of pig microbial community structure and functional capacities were notable. For example, Prevotella spp. has been reported to breakdown polysaccharides to short-chain fatty acids (SCFAs) through the production of enzymes, such as $\beta$-glucanase, mannase, and xylanase, which are capable of degrading plant cell wall [34,35]. In addition, the carbohydrates are metabolized by Lactobacilli and are fermented in the large intestine to SCFAs, which are finally utilized by the pigs as an energy source [36]. Thus, one of the major factors influencing abrupt shifts in the microbiota in piglets during weaning is the sudden alteration of diet from simple to more complex nutrient sources, which affects absorption capacity of the small intestine, and likely influences growth and feed efficiency.

\subsection{Intestinal Mucosa Immunity and Oxidative Stress}

The impacts of weaning stress are not limited to intestinal barrier function and gut microbiome but also observed in intestinal immunity and intestinal oxidative status of weaned pigs compared with pre-weaning pigs. The intestinal CD4+ and CD8+ T lymphocytes in pigs on day 2 post-weaning has been reported to increase sharply, thereby upregulating the mRNA expression of inflammatory cytokines such as tumor necrosis factor-alpha (TNF-a) and interleukins (IL-1b, IL-6, and IL-8) in the middle of jejunum [37,38], and a reduction in fecal immunoglobulin A (IgA) from day 5 after birth to 50 days of age was also reported [39]. In addition, the upregulation of matrix metalloproteinase through activation of immune cell and downregulation of major histocompatibility complex (MHC) class I expression in jejunal mucosa were observed in weaned pigs, resulting in atrophied villus and increased concentration of plasma cortisol [37,40]. These observations suggest that weaning induces a transient gut inflammation in pigs.

Increased oxidation processes due to weaning stress lead to the release of excessive reactive oxygen species which could eventually modify certain proteins in the cell and trigger the upregulation of pro-inflammatory cytokines, thereby negatively affecting the expression of tight junction proteins and causing increased gut permeability [41,42]. 


\subsection{Feed Intake and Performance during Weaning Transition}

As mentioned above, the functions of the GIT extend beyond digestion and the subsequent active or passive absorption of nutrients and electrolytes, barrier function, maintenance of bodily fluid balance, secretion of digestive enzymes, immunoglobulins, and multiple other components, as they also play an influential role in the regulation of epithelial and immune functions for normal biological functioning and homeostasis in both the GIT and the body $[9,43]$. After weaning at the age of 3-4 weeks, piglets have no choice other than adapting to a solid dry diet that is less digestible and palatable as compared with highly digestible and palatable dam's milk in the liquid form pre-weaning. Apart from this nutritional challenge, weaning is simultaneously involved in social and environmental stressors, consequently leading to a low feed intake [44], reduced growth, and behavioral disturbances [45] along with gastrointestinal problems $[23,46]$. In a review by Dividich and Seve [44], it has been indicated that the intake of metabolizable energy (ME) is reduced by $30-40 \%$ of pre-weaning milk intake, and to achieve full recovery to the pre-weaning ME intake level, it takes approximately 2 weeks post-weaning. This low feed intake during the post-weaning period may contribute to intestinal inflammation adversely affecting intestinal integrity resulting in the reduction of villus height and an increase in crypt depth [37]. It is obvious that growth performance is reduced with low feed intake. For instance, a loss of 100-250 g body weight (BW) is reported at the first day of weaning regardless of weaning age, which is recovered by 4 days post-weaning [44]. The BW gain above $227 \mathrm{~g}$ /day during the first week after weaning led to the reduction in days to market by 6-10 days compared to BW gain by less than $150 \mathrm{~g} / \mathrm{d}$ during the first week, indicating the days of weight gain in the first week after weaning impacts the total days to market [47]. Thus, it is of utmost importance to enhance the feed consumption and growth in weaned pigs as soon as possible. Although it is difficult to prevent some of the reduction in BW during weaning transition, it is necessary to understand the impact of reduced feed intake due to weaning stress and its concomitant impact on performance and take appropriate measures to reduce the negative effects.

For the improvement of nutrient digestion and absorption, regulation of gut microbiota, as well as modulation of immune system so as to enhance disease resistance and nutritional intervention along with management techniques have been considered as a good strategy $[5,6,48-50]$.

\section{Nutritional Intervention and Mechanistic Aspects}

Nutritional strategies, such as optimizing dietary proteins or energy content and the use of feed additives at post-weaning, have been implemented to minimize the weaninginduced stress. In an era of reduced/banned antibiotic growth promoters, the supplementation of different feed additives such as probiotics, prebiotics, organic acids, plant extracts, short-chain fatty acids, polyunsaturated fatty acids, etc. have been shown from various studies to beneficially influence growth performance and the compromised state of gut health of the young pig after weaning (Table 1). For conducting this review, a literature search was performed using PubMed, Science Direct, Google scholar, and Web of Science databases. Data collection was performed based on 148 articles published during the years 1986-2021. Ziegler et al. [51] pointed out that the fundamental physiologic, anatomic, and nutritional similarities exist between pigs and humans, and both share similar gut microbial profiles [52]. 
Table 1. Effects of different types of feed additives on gut health and performance of young pigs.

\begin{tabular}{|c|c|c|c|c|c|c|}
\hline Additive Type & Composition & $\begin{array}{c}\text { Age of } \\
\text { Piglets/Experiment } \\
\text { Duration }\end{array}$ & Dose & $\begin{array}{l}\text { Intestinal Structure, } \\
\text { Gut/Health Microbiota }\end{array}$ & $\begin{array}{l}\text { Performance/Other } \\
\text { Observations }\end{array}$ & References \\
\hline \multicolumn{7}{|c|}{ Fatty acid (FA) } \\
\hline $\begin{array}{l}\text { Medium-chain fatty } \\
\text { acid }\end{array}$ & Caprylic or capric acid & 32 days old / $49-d$ trial & $2 \mathrm{~g} / \mathrm{kg}$ & $\begin{array}{c}\text { Reduced Clostridium perfringens } \\
\text { levels;improved mucosal } \\
\text { epithelium structure of ileum }\end{array}$ & $\begin{array}{l}\text { Improved overall ADG. FCR } \\
\text { in pigs receiving diet } \\
\text { supplemented with caprylic } \\
\text { acid was better; increased } \\
\text { digestibility and reduced } \\
\text { mortality }\end{array}$ & [53] \\
\hline $\begin{array}{l}\text { Poly unsaturated fatty } \\
\text { acids }\end{array}$ & Coated n-3 FA & 28 days old $/ 42-\mathrm{d}$ trial & 5,10 and $15 \mathrm{~g} / \mathrm{kg}$. & $\begin{array}{l}\text { Trends in linear increment in } \\
\text { fecal Lactobacillus counts at } \\
\text { weeks } 3 \text { and } 6\end{array}$ & $\begin{array}{c}\text { Linear increase in ADG } \\
\text { during week } 1,3 \text { and overall, } \\
\text { G:F linearly increased during } \\
\text { overall; linear increase in DM } \\
\text { and N digestibility at the end } \\
\text { of experiment }\end{array}$ & [54] \\
\hline \multicolumn{7}{|c|}{ Nucleotides } \\
\hline & $\mathrm{UMP} / \mathrm{UR}$ & 12 days old/10-d trail & $\begin{array}{c}476 \text { mg UP, } 348 \text { mg } \\
\text { UR(orally) }\end{array}$ & $\begin{array}{l}\text { Decreased the diarrhea rate, UR } \\
\text { increased the jejunum villus } \\
\text { length/crypt depth ratio, } \\
\text { Claudin-3, and E-cadherin } \\
\text { expression, and the pyrimidine } \\
\text { nucleotide metabolic enzymes } \\
\text { in the duodenal mucosa, UMP } \\
\text { and UR decreased the } \\
\text { expression of CAD and RRM2 at } \\
\text { the jejunal mucosa }\end{array}$ & $\begin{array}{l}\text { UMP and UR supplements } \\
\text { improved the ADG of piglets }\end{array}$ & [56] \\
\hline
\end{tabular}


Table 1. Cont.

\begin{tabular}{|c|c|c|c|c|c|c|}
\hline Additive Type & Composition & $\begin{array}{c}\text { Age of } \\
\text { Piglets/Experiment } \\
\text { Duration }\end{array}$ & Dose & $\begin{array}{l}\text { Intestinal Structure, } \\
\text { Gut/Health Microbiota }\end{array}$ & $\begin{array}{l}\text { Performance/Other } \\
\text { Observations }\end{array}$ & References \\
\hline & $\begin{array}{l}\text { UMP, GMP, AMP, CMP, } \\
\text { and IMP }\end{array}$ & 28 days old / $28-d$ trial & $0.8 \mathrm{~g} / \mathrm{head} /$ day & $\begin{array}{l}\text { No differences in gene } \\
\text { expression levels of } \\
\text { inflammatory cytokines (IL1 } \alpha \text {, } \\
\text { IL1 } \beta, \text { IL6, IL10, TNF } \alpha \text {, TLR2, } \\
\text { TLR4, and PPAR) at ileal Peyer's } \\
\text { patches level; no effect on IgA } \\
\text { and IgG content in blood }\end{array}$ & $\begin{array}{l}\text { Increased BW and ADG but } \\
\text { not G:F }\end{array}$ & [57] \\
\hline \multicolumn{7}{|c|}{ Organic acid (OA) } \\
\hline & $\begin{array}{l}\text { Pure OA (propionic } \\
\text { acid, lactic acid, formic } \\
\text { acid, malic acid, citric } \\
\text { acid, or fumaric acid) }\end{array}$ & 25 days old / 28 -d trial & $\begin{array}{l}\text { 10, } 16,12,12,15 \text {, and } 15 \\
\mathrm{~g} / \mathrm{kg} \text {, respectively }\end{array}$ & $\begin{array}{l}\text { Reduced incidence and severity } \\
\text { of diarrhea }\end{array}$ & $\begin{array}{l}\text { Heavier BW, and increased } \\
\text { ADG and FI especially with } \\
\text { lactic acid supplementation }\end{array}$ & [58] \\
\hline & Formic acid & 35 days old /42-d trial & $\begin{array}{l}0,1.4 \mathrm{~g} / \mathrm{kg} \text { (low formic } \\
\text { acid; LFA), or } 6.4 \mathrm{~g} / \mathrm{kg} \\
\text { (high formic acid; HFA) }\end{array}$ & $\begin{array}{l}\text { Increased microbiota diversity } \\
\text { in high FA group }\end{array}$ & $\begin{array}{l}\text { Increased ADG, ADFI and } \\
\text { improved feed efficiency } \\
\text { during the first three weeks in } \\
\text { both high and low OA group }\end{array}$ & [59] \\
\hline & $\begin{array}{l}17 \% \text { fumaric acid, } 13 \% \\
\text { citric acid, } 10 \% \text { malic } \\
\text { acid, and } 1.2 \% \\
\text { medium-chain fatty } \\
\text { acid (protected OA) }\end{array}$ & 28 days old /42-d trial & 1 and $2 \mathrm{~g} / \mathrm{kg}$ & $\begin{array}{l}\text { Reduction in E. coli counts at } \\
\text { week } 3 \text { and increase in } \\
\text { Lactobacillus counts in week } 6 \\
\text { with } 2 \mathrm{~g} / \mathrm{kg} \text { organic acid }\end{array}$ & $\begin{array}{c}\text { Increased overall ADG and } \\
\text { ADFI }\end{array}$ & {$[60]$} \\
\hline & $\begin{array}{l}\text { Formic acid, acetic } \\
\text { acid, and propionic } \\
\text { acid combined with } \\
\text { medium chain fatty } \\
\text { acids }\end{array}$ & 28-d trial & $3 \mathrm{~g} / \mathrm{kg}$ & $\begin{array}{l}\text { Reduced the incidence of } \\
\text { diarrhea and fecal E. coli counts, } \\
\text { the ratio of villus } \\
\text { height-to-crypt depth in the } \\
\text { jejunum and ileum was higher }\end{array}$ & $\begin{array}{c}\text { Digestibility of dry matter, } \\
\text { total carbohydrates, NDF, and } \\
\text { ADF was increased during } \\
\text { days 14-28 }\end{array}$ & {$[61]$} \\
\hline & $\begin{array}{l}17 \% \text { fumaric acid, } 13 \% \\
\text { citric acid, } 10 \% \text { malic } \\
\text { acid, and } 1.2 \% \\
\text { medium-chain fatty } \\
\text { acid }\end{array}$ & 28 days old $/ 42-d$ trial & 0,1 , and $2 \mathrm{~g} / \mathrm{kg}$ & $\begin{array}{l}\text { Linear increase in fecal } \\
\text { Lactobacillus counts and linear } \\
\text { reduction in E. coli and } \\
\text { Salmonella counts }\end{array}$ & $\begin{array}{c}\text { Increase in overall ADG and } \\
\text { DM digestibility }\end{array}$ & [62] \\
\hline
\end{tabular}


Table 1. Cont.

\begin{tabular}{|c|c|c|c|c|c|c|}
\hline Additive Type & Composition & $\begin{array}{c}\text { Age of } \\
\text { Piglets/Experiment } \\
\text { Duration }\end{array}$ & Dose & $\begin{array}{l}\text { Intestinal Structure, } \\
\text { Gut/Health Microbiota }\end{array}$ & $\begin{array}{l}\text { Performance/Other } \\
\text { Observations }\end{array}$ & References \\
\hline \multicolumn{7}{|c|}{ Prebiotics } \\
\hline & Fructo-oligosaccharide & 33 days old/21-d trial & $4 \mathrm{~g} / \mathrm{kg}$ & $\begin{array}{l}\text { Increased villus height, reduced } \\
\text { diarrhea }\end{array}$ & $\begin{array}{l}\text { Improved ADG, increased the } \\
\text { concentrations of isobutyric } \\
\text { and butyric acid and total } \\
\text { VFAs in the caecum, and } \\
\text { acetic acid, isovaleric acid, and } \\
\text { total VFAs in feces }\end{array}$ & {$[63]$} \\
\hline & Resistant starch & 17 days old/21-d trial & 70 and $140 \mathrm{~g} / \mathrm{kg}$ & $\begin{array}{l}\text { Enhanced microbial diversity in } \\
\text { colon and reduced diarrhea } \\
\text { with } 7 \% \text { resistant starch } \\
\text { inclusion in the diet }\end{array}$ & $\begin{array}{l}\text { No effect on growth } \\
\text { performance }\end{array}$ & {$[64]$} \\
\hline & Inulin & 42 day old/35-d trial & $40 \mathrm{mg} / \mathrm{kg}$ & $\begin{array}{l}\text { Increased Lactobacilli and } \\
\text { Bifidobacteria and reduced } \\
\text { Enterobacteriaceae and } \\
\text { Clostridium spp. in the lumen } \\
\text { and mucosa of gut }\end{array}$ & Higher blood hemoglobin & [65] \\
\hline & Lactulose & 25 days old/18-d trail & $10 \mathrm{~g} / \mathrm{kg}$ & $\begin{array}{l}\text { Increased Lactobacilli and the } \\
\text { percentage of butyric acid in the } \\
\text { colon; an increase in the ileum } \\
\text { villous height }\end{array}$ & $\begin{array}{l}\text { Improved the ADG; reduction } \\
\text { of the pig major acute-phase } \\
\text { protein in serum }\end{array}$ & {$[66]$} \\
\hline & Levan-type fructan & 28 days old / $42-d$ trial & $0,0.1,0.5$, and $1.0 \mathrm{~g} / \mathrm{kg}$ & $\begin{array}{l}\text { Linear increase in fecal lactic } \\
\text { acid bacteria counts with the } \\
\text { increase in the dose of levan }\end{array}$ & $\begin{array}{c}\text { Increased ADG and ADFI } \\
\text { linearly during days } 0-21 \text { and } \\
\text { overall; linear increase in the } \\
\text { digestibility of DM, CP, and } \\
\text { GE }\end{array}$ & [67] \\
\hline
\end{tabular}


Table 1. Cont.

\begin{tabular}{|c|c|c|c|c|c|c|}
\hline Additive Type & Composition & $\begin{array}{c}\text { Age of } \\
\text { Piglets/Experiment } \\
\text { Duration }\end{array}$ & Dose & $\begin{array}{l}\text { Intestinal Structure, } \\
\text { Gut/Health Microbiota }\end{array}$ & $\begin{array}{l}\text { Performance/Other } \\
\text { Observations }\end{array}$ & References \\
\hline & $\begin{array}{c}\text { Galacto } \\
\text { oligosaccharide (GOS) }\end{array}$ & 28 days old $/ 28-d$ trial & $\begin{array}{c}0,500,1000,1500, \text { and } \\
2000 \mathrm{mg} / \mathrm{kg}\end{array}$ & $\begin{array}{c}\text { Increased the number of } \\
\text { Lactobacillus and Bifidobacterium, } \\
\text { and decreased the number of } E \text {. } \\
\text { coli in a linear or quadratic } \\
\text { dose-dependent manner; } \\
\text { decreased serum concentration } \\
\text { of pro-inflammatory cytokines } \\
\text { but increased anti-inflammatory } \\
\text { cytokines in a linear or } \\
\text { quadratic dose-dependent } \\
\text { manner }\end{array}$ & $\begin{array}{l}\text { Promoted the growth and } \\
\text { activities of antioxidant } \\
\text { enzyme in a linear or } \\
\text { quadratic dose-dependent } \\
\text { manner }\end{array}$ & [68] \\
\hline \multicolumn{7}{|c|}{ Probiotics } \\
\hline & Saccharomyces cerevisiae & 27 days old/35-d trial & $1.25 \mathrm{~g} / \mathrm{kg}$ & $\begin{array}{c}\text { Villus length and crypt depth } \\
\text { not affected by probiotic but } \\
\text { were greater at } 5 \text { weeks vs. } 2 \\
\text { weeks after weaning; CD4 and } \\
\text { CD8 cells were lower at } 5 \text { week } \\
\text { after weaning }\end{array}$ & Improved ADG and G:F & [69] \\
\hline & Lactobacillus sobrius & $\begin{array}{l}21 \text { days old (challenged } \\
\text { with } 1.5 \mathrm{~mL} \text { suspension } \\
\text { of } 10^{10} \mathrm{CFU} \text { ETEC F4) }\end{array}$ & $\begin{array}{l}10^{10} \text { CFU probiotic in } 1 \\
\text { mL skimmed milk/day }\end{array}$ & $\begin{array}{c}\text { Reduced ETEC levels in the } \\
\text { ileum }\end{array}$ & Improved daily weight gain & {$[70]$} \\
\hline & Saccharomyces cerevisiae & 21 days old/21-d trial & $5,10,20 \mathrm{~g} / \mathrm{kg}$ probiotic & $\begin{array}{l}\text { Increase in jejunal villus height } \\
\text { and villus height: crypt depth } \\
\text { ratio was also increased; gut } \\
\text { IFN-gamma concentration } \\
\text { increased on day } 21 \text { but plasma } \\
\text { IFN-gamma reduced on day } 7 \\
\text { and CD4 reduced on day } 14\end{array}$ & $\begin{array}{c}\text { Feed intake was enhanced } \\
\text { with the inclusion of } 5 \text { or } 10 \\
\mathrm{~g} / \mathrm{kg} \text {; enhanced digestibility } \\
\text { of DM, CP, GE with } 5 \mathrm{~g} / \mathrm{kg} \\
\text { yeast supplement }\end{array}$ & {$[71]$} \\
\hline
\end{tabular}


Table 1. Cont.

\begin{tabular}{|c|c|c|c|c|c|c|}
\hline Additive Type & Composition & $\begin{array}{c}\text { Age of } \\
\text { Piglets/Experiment } \\
\text { Duration }\end{array}$ & Dose & $\begin{array}{l}\text { Intestinal Structure, } \\
\text { Gut/Health Microbiota }\end{array}$ & $\begin{array}{l}\text { Performance/Other } \\
\text { Observations }\end{array}$ & References \\
\hline & $\begin{array}{l}\text { Lactobacillus johnsonii } \\
\text { and Lactobacillus } \\
\text { mucosae single or } \\
\text { combined }\end{array}$ & 21 days old/21-d trial & $\begin{array}{c}5 \times 10^{7} \text { or } 10^{8} \\
\mathrm{CFU} / \mathrm{g} / \text { piglet/day of } \\
\text { each strain }\end{array}$ & $\begin{array}{l}\text { Increase in fecal Lactobacillus } \\
\text { and reduction in E. coli counts }\end{array}$ & $\begin{array}{l}\text { Both single or combined } \\
\text { supplementation increased } \\
\text { overall FI and BWG }\end{array}$ & {$[72]$} \\
\hline & Enterococcus faecalis & 24-26 days old/28-d trial & $\begin{array}{c}0.5 \times 10^{9}, 1 \times 10^{9}, \text { or } 2.5 \\
\times 10^{9} \mathrm{CFU} / \mathrm{kg} \text { of feed }\end{array}$ & $\begin{array}{l}\text { Lower incidence of diarrhea and } \\
\text { increase in fecal Lactobacillus } \\
\text { counts }\end{array}$ & $\begin{array}{l}\text { Higher ADG and feed } \\
\text { efficiency in pigs receiving the } \\
\text { highest probiotic dose. }\end{array}$ & [73] \\
\hline & $\begin{array}{l}\text { Bacillus subtilis } \\
\text { GCB-13-001 }\left(1 \times 10^{9}\right. \\
\text { CFU } / \mathrm{kg})\end{array}$ & 28 days old /42-d trial & $1 \mathrm{~g} / \mathrm{kg}$ & $\begin{array}{l}\text { Fecal Lactobacillus counts were } \\
\text { improved, and E. coli counts } \\
\text { were reduced }\end{array}$ & $\begin{array}{l}\text { The BW and ADG improved } \\
\text { during all phases, F:G } \\
\text { improved during the overall } \\
\text { experiment period }\end{array}$ & {$[74]$} \\
\hline & $\begin{array}{l}\text { B. coagulans, } B \text {. } \\
\text { licheniformis, } B \text {. subtilis, } \\
\text { and C. butyricum } \\
\text { mixed dried spores }(1 \\
\times 10^{12}, 5 \times 10^{11}, 1 \times \\
10^{12} \text { and } 1 \times 10^{11} \\
\text { CFU } / \mathrm{kg} \text { respectively). }\end{array}$ & 28 days old $/ 42-\mathrm{d}$ trial & $0,1,2$, and $3 \mathrm{~g} / \mathrm{kg}$ & $\begin{array}{l}\text { Linear increase in fecal } \\
\text { Lactobacillus counts and } \\
\text { decreased Escherichia coli counts } \\
\text { and ammonia (NH3) emission }\end{array}$ & $\begin{array}{l}\text { Linearly increased ADG and } \\
\text { ADFI during } d 0-7 \text {, increased } \\
\text { ADG and G:F during d 8-21 }\end{array}$ & [75] \\
\hline & $\begin{array}{l}\text { Bacillus subtilis or } \\
\text { Bacillus pumilus } 1 \times \\
10^{9} \mathrm{CFU} / \mathrm{kg}\end{array}$ & $\begin{array}{l}21 \text { days old (challenged } \\
\text { with ETEC/28-d trail) }\end{array}$ & $500 \mathrm{mg} / \mathrm{kg}$ & $\begin{array}{l}\text { Bacillus subtilis supplement } \\
\text { alleviated diarrhea severity, } \\
\text { enhanced gut health, and } \\
\text { reduced systemic inflammation } \\
\text { of weaned pigs infected with } \\
\text { ETEC F18 }\end{array}$ & $\begin{array}{c}\text { Bacillus subtilis } \\
\text { supplementation improved } \\
\text { growth performance }\end{array}$ & [76] \\
\hline \multicolumn{7}{|c|}{ Phytogenics } \\
\hline Mixture of herb extract & $\begin{array}{l}\text { Buckwheat, thyme, } \\
\text { curcuma, black pepper, } \\
\text { and ginger }\end{array}$ & 21 days old /42-d trial & $250 \mathrm{mg} / \mathrm{kg}$ & Reduced fecal E. coli counts & $\begin{array}{l}\text { Improved energy digestibility } \\
\text { but no effect on growth } \\
\text { performance }\end{array}$ & [77] \\
\hline
\end{tabular}


Table 1. Cont.

\begin{tabular}{|c|c|c|c|c|c|c|}
\hline Additive Type & Composition & $\begin{array}{c}\text { Age of } \\
\text { Piglets/Experiment } \\
\text { Duration }\end{array}$ & Dose & $\begin{array}{l}\text { Intestinal Structure, } \\
\text { Gut/Health Microbiota }\end{array}$ & $\begin{array}{l}\text { Performance/Other } \\
\text { Observations }\end{array}$ & References \\
\hline Plant extract(PE) & $\begin{array}{l}\text { Green tea leaves } \\
\text { (Camellia sinensis) and } \\
\text { pomegranate fruit } \\
(\text { Punica granatum) }\end{array}$ & 24 days old/35-d trial & $\begin{array}{c}8 \mu \mathrm{L} / \mathrm{kg} \text { per day } \mathrm{PE} \text { in } \\
\text { drinking water }\end{array}$ & $\begin{array}{l}\text { Reduced fecal E. coli counts in } \\
\text { challenged pigs on days } 14 \text { and } \\
\quad 35 \text { and reduced } \\
\text { Enterobacteriaceae on day } 35\end{array}$ & $\begin{array}{l}\text { Increased ADG from days } \\
28-35 \text { and increase G:F ratio } \\
\text { from days } 7 \text { to } 14\end{array}$ & {$[78]$} \\
\hline $\begin{array}{l}\text { Brown algae (ethanol } \\
\text { extract from Ecklonia } \\
\text { sp.) }\end{array}$ & Eckol & 28 days old/42-d trial & 0.5 and $1 \mathrm{~g} / \mathrm{kg}$ & $\begin{array}{l}\text { Improved intestinal barrier } \\
\text { function }\end{array}$ & $\begin{array}{c}\text { Improved growth } \\
\text { performance, and reduced the } \\
\text { levels of stress hormones } \\
\text { (cortisol, epinephrine, and } \\
\text { norepinephrine) and } \\
\text { antioxidants (superoxide } \\
\text { dismutase and glutathione } \\
\text { peroxide) }\end{array}$ & [79] \\
\hline
\end{tabular}

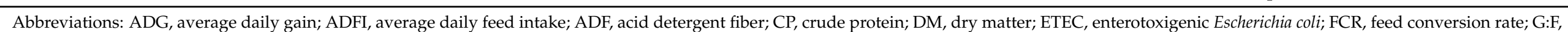

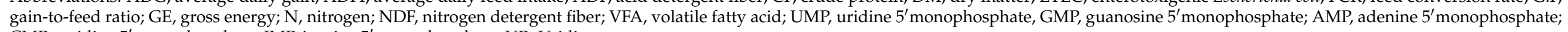
CMP, cytidine $5^{\prime}$ monophosphate; IMP, inosine $5^{\prime}$ monophosphate; UR, Uridine. 
Therefore, certain aspects of work can be applied to pigs, particularly the mechanistic studies focused on the interaction between certain additives and the host mucosal surface or pathogenic bacteria.

\subsection{Nucleotides}

Nucleotides are a group of bioactive agents that take part in building DNA or RNA, in various biochemical processes, biosynthetic pathways, and coenzyme components and are absorbed as nucleosides by the intestinal epithelium [80-82]. Research has shown that exogenous supplementation of nucleotides induces positive effects on intestinal hyperemia, immune response, small intestinal growth, intestinal microbiome, and hepatic composition in pigs [83-86], as well as increased BW and average daily gain (ADG) in weaning pigs [57]. Sauer et al. [81] noted that dietary nucleotides supplementation to single stomached animals positively affected nutrient metabolism, intestinal morphology, and function, immune function, intestinal microbiota, as well as growth performance. A recent study by Jang and Kim [55] demonstrated that nucleotide supplementation reduces intestinal inflammation and oxidative stress and improves intestinal villi structure and energy digestibility. Moreover, there is a high need of nucleotide especially during periods of growth, stress, and immunodeficiency in newly weaned pigs [87] since piglet starter diets are nucleotide deficient [88]. The in vivo feeding trial performed by Lee and Kim [89] in weaned pigs showed that nucleotide supplementation resulted in enhanced growth performance and intestinal morphology as well as reduction in serum stress levels which corroborated with findings of previous studies $[81,90]$ which demonstrated that dietary nucleotide, when supplemented at greater than physiological quantities, improved growth performance and plasma cortisol levels as well as enhanced the adaptive capabilities of piglets to weaning stress during the first 2 weeks after weaning.

Feeding a diet supplemented with nucleotide to low-birth-weight pigs has been reported to markedly increase gene expressions of Toll-like receptors (TLR-9, TLR-4) and Toll-interacting protein (TOLLIP), indicating the effect of nucleotides supplementation on eliciting intestinal innate immunity and mounting acquired immune response [82]. In addition, supplementing nucleotides led to the upregulation of tight junction proteins such as Claudin-1 and ZO-1 in ileum of piglets [82] as well as Claudin-3 and E-cadherin expression, and the pyrimidine nucleotide metabolic enzymes in the duodenal mucosa [56] which may eventually aid in alleviating gut health problem by improving intestinal barrier functions in weanling pigs.

The effects of exogenous nucleotide during the weaning transition were evaluated using gene expression profiling of the small intestine of pigs after dietary treatment with nucleotides by Lee and Kim [89]. Genes that were significantly regulated by nucleotide were identified and further study was conducted to assess the regulatory functions for small intestinal development in pigs. Among the top 10 upregulated genes, Trefoil factor 3 (TFF3) and SAM-pointed domain-containing ETS transcription factor (SPDEF) were found to have a significant role in wound healing and intestinal barrier function. In addition, when lipopolysaccharide-challenged IPEC-J2 intestinal porcine enterocyte cells were treated with nucleosides and TFF3, it resulted in increased intestinal trans-epithelial electrical resistance and decreased intestinal permeability. Finally, Lee and Kim [89] showed that nucleotide treatment induced the expression of SPDEF in a dose-dependent manner, resulting in modulation of TFF3-mediated wound healing and intestinal barrier function via the phosphatidylinositol 3-kinase/Akt, extracellular signal-regulated kinase 1/2, p38, and Janus kinase/signal transducer and activator of transcription signaling pathways.

\subsection{Phytogenic Compound}

The effects of phytogenic feed additive on monogastric animals' performance and health have been thoroughly reviewed by Upadhaya and Kim [91] and Lillehoj et al. [92]. Different plant resources such as garlic, pepper, cinnamon, clove, fennel, oregano thyme, ginger, turmeric, rosemary, caraway, etc. enriched in bioactive phytochemicals have been 
reported to possess antimicrobial, anti-inflammatory, as well as antioxidant properties. These bioactive phytochemical compounds including allicin, capsaicin, eugenol, anethol, carvacrol, thymol, cinnamaldehyde, curcumin, etc. play an influential role in enhanced disease resistance and growth performance. The observed beneficial effects can be associated with improved gut health, such as improved intestinal barrier integrity $[93,94]$, due to the upregulation of genes such as MUC2 and genes encoding claudins and occludins related to tight junctions and cell to cell junction in ileum. Yuan et al. [95] reported that by the dietary inclusion of flavones extracted from the leaves of Eucommia ulmoides enhanced intestinal morphology and integrity of diquat challenged pigs via improved intestinal barrier function. In addition, several other studies reported that supplementation of plant extract alone or in combination improved performance, digestibility, and intestinal barrier function in weaning pigs [77-79]. Ecklonia species (commonly known as brown algae) possessing a wide range of therapeutic properties, and enriched with vitamins, minerals, dietary fiber, proteins, and polysaccharide have received considerable attention in recent decades. The beneficial effects of increase in the dietary supplemental level of Ecklonia cava $(0 \%, 0.05 \%$, $0.1 \%, 0.15 \%$ ), consisting of phloroglucinol, eckol, phlorofucofuroeckol, and dieckol, were observed in cecal microflora and intestinal morphology. In addition to this, a linear increase in overall average daily gain and feed efficiency (Figure 1) in weaning pigs has been reported by Choi et al. [96]. To evaluate the molecular mechanism of how eckol mitigate intestinal dysfunction, the changes in gene expression and intestinal function after Eckol treatment during the suckling-to-weaning transition were evaluated by Lee and Kim [79]. These authors investigated the biological roles of differentially expressed genes (DEGs) in intestinal development by assessing intestinal wound healing and barrier functions, as well as the associated signaling pathways and oxidative stress levels. An in vivo trial with eckol in weaning pigs altered the gene expression in intestinal samples and the expression patterns were confirmed in the small intestine. Furthermore, according to Lee and Kim [79], treating the IPEC-J2 intestinal porcine enterocyte cell line with different concentrations ranging from 10 to $200 \mu \mathrm{M}$ of eckol and incubating for $24 \mathrm{~h}$ resulted in a concentrationdependent increase in pancreatic and duodenal homeobox (PDX)1, and heparin-binding EGF-like growth factor (HBEGF) mRNA and protein levels. Additionally, eckol alleviated $\mathrm{H}_{2} \mathrm{O}_{2}$-induced oxidative stress through PI3K/AKT, P38, and 5'-AMP-activated protein kinase (AMPK) signaling pathways. Thus, eckol was found to be a potential candidate in modulating intestinal barrier functions, wound healing, and oxidative stress through PDX/HBEGF, thereby improving growth during the suckling-to-weaning transition.

\subsection{Probiotics}

The non-pathogenic, viable microorganisms possessing the ability to reach the intestines in sufficient numbers and conferring beneficial impact on host are termed as probiotics [97,98]. Lactobacillus species, Bifidobacterium species, Escherichia coli (E. coli), Bacillus species, and Saccharomyces species are the commonly used probiotics either alone or in combination. Several studies have shown that different probiotics strains' application beneficially impacted intestinal integrity, fecal microbial counts, enhanced gut health, and improved performance in weaning pigs [69-76]. In addition, our previous study showed that Salmonella-challenged weaning pigs, when fed diet supplemented with $0.1 \%$ B. subtilis RX7 containing $1 \times 10^{9} \mathrm{cfu} / \mathrm{g}$ or B. methylotrophicus C14 containing $1 \times 10^{9} \mathrm{cfu} / \mathrm{g}$, exerted positive immunomodulatory effects [99]. The major functions of probiotics include competitive adherence to the mucus and epithelium, enhanced intestinal barrier function, as well as immunomodulatory effects $[100,101]$. The abatement of barrier disruption by certain Lactobacillus species is through upregulation of tight junction proteins. For instance, an increase in occludin protein expression has been reported by the use of L. acidophilus and $L$. plantarum [102,103]. In addition to this, apical relocalization of ZO-1 and occludin through stimulation of Toll like receptor 2 has been reported to be induced by L. plantarum [104,105]. The preservation of barrier function by Bifidobacterium has been suggested to be due to the maintenance of tight junction confirmation [106]. Another reported mechanism of 
probiotics to improve barrier function and exclusion of pathogens is due to enhancement in mucin expression. In human cell lines Caco-2 (MUC2) and HT29 (MUC2 and 3), several Lactobacillus species have been reported to increase mucin expression, thereby blocking pathogenic E. coli invasion and adherence $[107,108]$. Despite the promising effects of probiotics on intestinal barrier homeostasis and repair, the potential drawbacks and limitations of probiotic therapy cannot be ignored. For instance, Shanahan [109] highlighted the potential risks of probiotic since no probiotic can be regarded with zero risk and noted that the adverse effect of a probiotic product depends on the safety of the product, physiological state, and susceptibility of host.

$\mathrm{P}=0.045$, linear effect

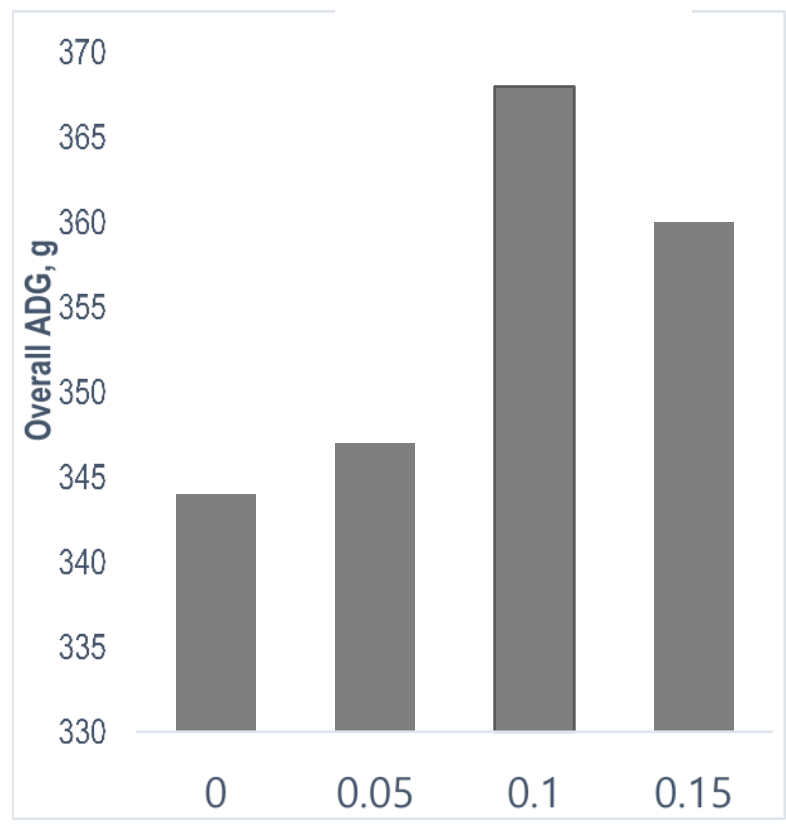

$\mathrm{P}=0.11$, linear effect

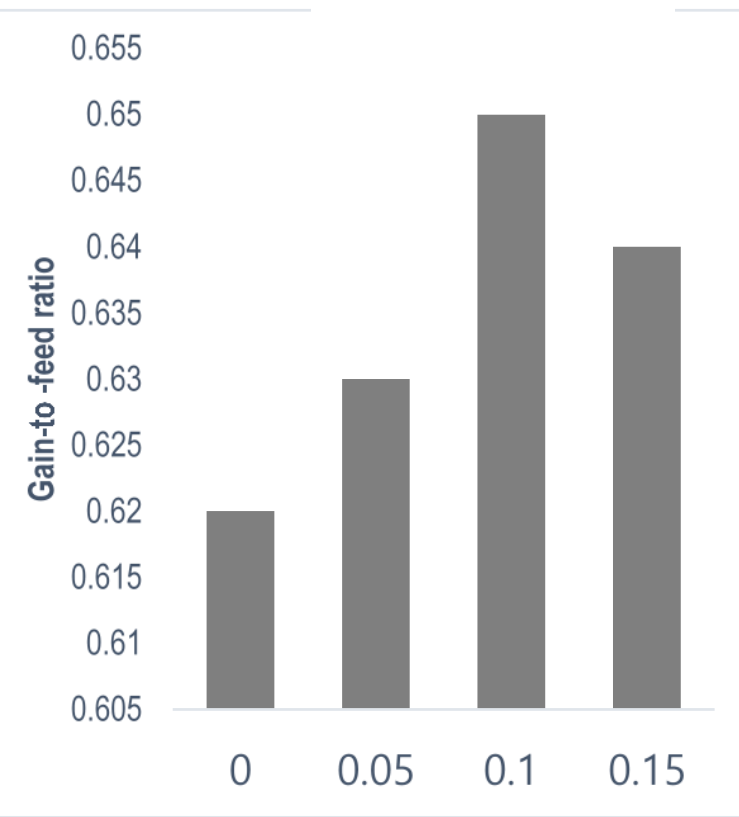

Figure 1. Effect of dietary supplementation of increasing doses of E. cava (\%) on overall average daily gain (ADG) and gain-to-feed ratio (G:F) in weaning pigs.

\subsection{Prebiotics}

The indigestible food ingredients' ability to selectively stimulate the proliferation and activity of beneficial microorganisms, thereby benefiting the host, is known as prebiotics [110]. The beneficial effects of several prebiotics such as fructo-oligosaccharide, levan-type fructan, inulin, lactulose, galacto-oligosaccharide, and resistant starch on weanling pigs have been reported by several studies [63-68]. The proposed mechanisms of action of many prebiotics are due to the enhancement of the intestinal barrier function via the modulation of intestinal tight junction [111]. In in vivo studies by Wang et al. [112,113] on suckling piglets and LPS-challenged mice, it was demonstrated that galacto-oligosaccharide pretreatment led to the upregulation of ZO-1, occludin, and claudin-1 gene expression. In an in vitro study, a significant upregulation of tight junction genes including occludin, claudin3, and ZO-1 was observed with the supplementation of inulin fermentation products to porcine intestinal epithelial cells [114]. The supplementation with fructo-oligosaccharides and butyrate to T84 human colonic epithelial cells and Caco- 2 cells, respectively, resulted in the redistribution of proteins, including $\mathrm{ZO}-1$ and occludin, to the vicinity of the tight junctions [115,116]. A reasonable explanation for these observed changes in tight junction protein expression and distribution is due to the direct effects of prebiotic on gut microbiota. As revealed from different studies in conjunction with the changes mentioned above in the epithelial barrier, prebiotic supplementation also results in robust activation of 
AMP-activated protein kinase (AMPK) [115-117] which may eventually have a significant modulatory effect on intestinal tight junction proteins.

\subsection{Fatty Acids}

Based on their carbon chain length, fatty acids are classified into short-chain fatty acids (SCFAs; $1-5$ carbon atoms), medium-chain fatty acids (MCFAs; $6-12$ carbon atoms), or long-chain fatty acids (LCFAs; $13-21$ carbon atoms). In addition to this, fatty acids are classified into saturated or unsaturated fatty acids according to saturation level. These fatty acids possess bacteriostatic or bactericidal properties and are used as a pig feeding strategy.

The SCFA such as butyrate supplementation in salt form (sodium n-butyrate) in weaning pigs has been reported to promote the performance traits in weaning pigs; inhibit the proliferation of pathogenic bacteria; and enhance nutrient digestion, absorption, and gut barrier function of piglets [118-120]. A recent study by Upadhaya et al. [121] also showed that the dietary supplementation of coated sodium butyrate at low and medium doses to lactose- and sodium-reduced diets improved overall ADG, and a low dose tended to improve ADFI in weaning pigs (Figure 2). In addition, this coated sodium butyrate improved villus height and the small intestinal microflora, suggesting its role in enhancing gut health.

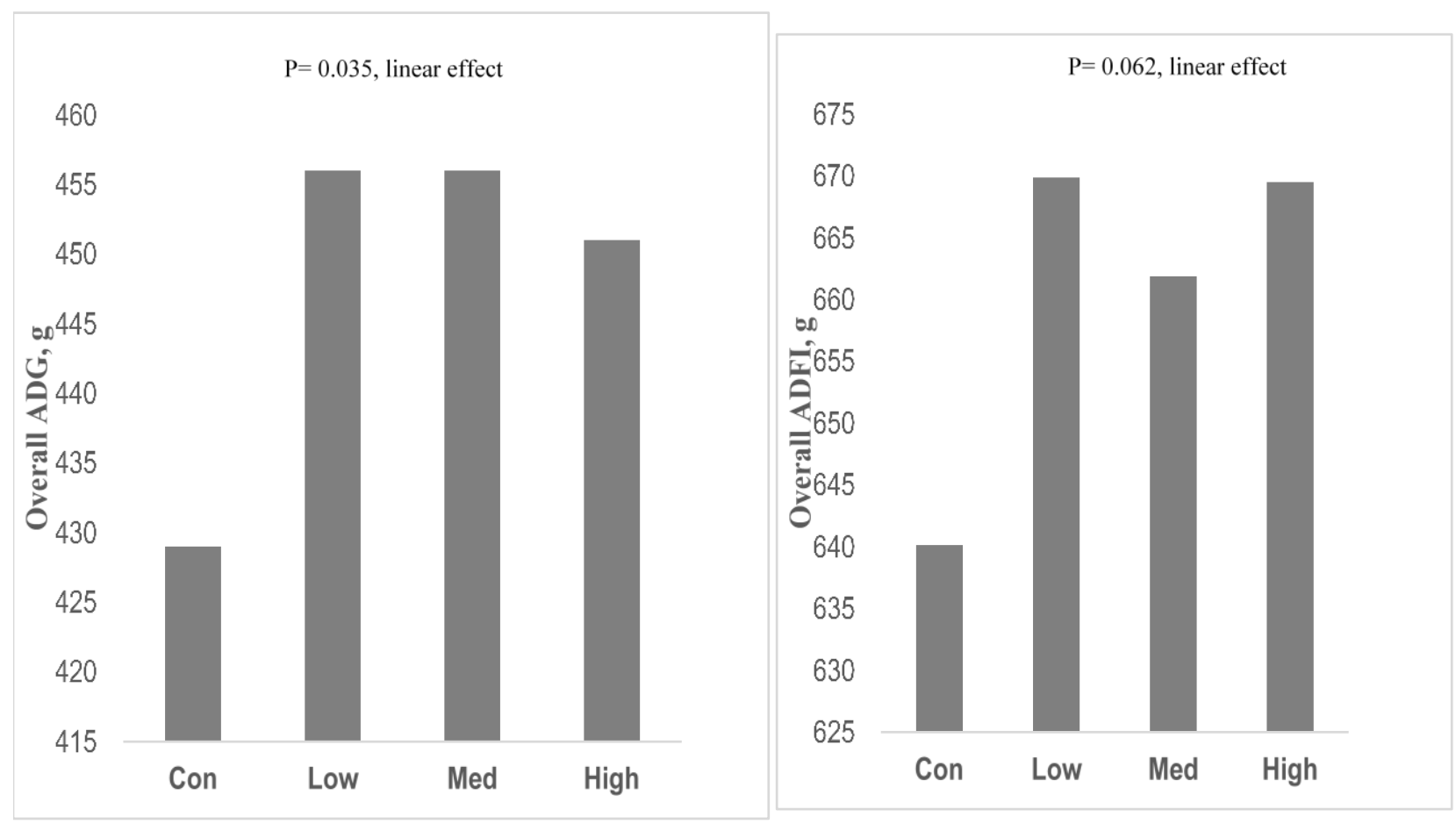

Figure 2. Effect of dietary supplementation of increasing dose of coated sodium butyrate acid on the overall average daily gain (ADG) and average daily feed intake (ADFI) of weaning pigs. Con, basal diet (lactose and sodium reduced); Low, Con $+0.5 \mathrm{~kg} /$ ton coated sodium butyrate; Med, Con $+1.5 \mathrm{~kg} /$ ton coated sodium butyrate and after 3 weeks Con $+0.75 \mathrm{~kg} / \mathrm{ton}$; High, Con $+3.0 \mathrm{~kg} /$ ton coated sodium butyrate and after 3 weeks Con $+1.50 \mathrm{~kg} /$ ton .

Fatty acids exert inhibitory effects against microorganisms, but the minimum inhibitory concentrations differ depending on fatty acid types as well as the types of microorganisms and environmental $\mathrm{pH}$. The concentration of SCFA increases under low $\mathrm{pH}$, and can easily pass into the bacterial cells because of their higher intercellular $\mathrm{pH}$, consequently causing the dissociation of SCFA and thereby reducing the intracellular $\mathrm{pH}$ of microbial cells and subsequently changing the metabolism of bacterial cells [122].

The MCFAs and monoglycerides are antimicrobial agents with the ability to disrupt the phospholipid membrane surrounding the pathogens [123]. The anionic part of MCFAs 
has been suggested to produce a strong antibacterial effect resulting in the alteration of the physico-chemical characteristics of the GIT environment in which the microorganisms exist, thereby influencing the gene expression of microorganism and host. The inhibitory activity against Gram-positive bacteria is stronger than Gram-negative bacteria because of the variation in the structural make-up of the cell wall of Gram-positive and Gram-negative bacteria. A simpler, single lipid bilayer cell membrane structures is found in Gram-positive bacteria, whereas Gram-negative bacterial have more complex inner and outer membrane structures [124]. Previous studies reported that monoglyceride, lauric acid, and blends of caprylic and capric acids exhibited antibacterial activity against several bacterial pathogens in swine [125]. Earlier studies have also shown that MCFA supplementation resulted in improved performance, enhanced nutrient digestibility, and improved antioxidant capacity of weaned piglets [126,127]. In an in-vivo study by Lee and Kang, [128], it was demonstrated that the supplementation of $0.5 \%$ capric acid resulted in reduced oxidative stress and improved intestinal barrier function in miniature pigs with cyclophosphamideinduced intestinal inflammation, oxidative stress, and gut barrier function. In addition, in an in vitro cellular model, Wang et al. [129] reported that caprylic acid supplementation resulted in enhanced intestinal epithelial barrier function due to the increased expression of endogenous host defense peptides, such as $\beta$ defensin $[129,130]$.

Several studies in human have reported the broad spectrum of antibacterial activity of polyunsaturated fatty acids [131-133]. Their mechanism of action has been suggested to be due to the obstruction in the essential bacterial processes at the pathogen membrane level through the disruption of electron transport chain, uncoupling of oxidative phosphorylation, and cell lysis [134,135]. A study by Zhang et al. [54] reported that supplementation of coated omega-3 fatty acid at the doses of 5, 10, and $15 \mathrm{~g} / \mathrm{kg}$ showed trends in linear reduction in fecal E. coli counts and increments in Lactobacillus counts, suggesting that omega-3 fatty acid can also modulate gut microbials and enhance gut functions. In another study, Hanczakowska et al. [53] reported that supplementation of $2 \mathrm{~g} / \mathrm{kg}$ capric or caprylic acid improved performance and mucosal epithelium structure of ileum in weaning pigs. However, there are also reports in which the supplementation of omega-3 fatty acid derived from linseed and coated docosahexaenoic acid supplementation derived from fish oil did not have a detectable impact on fecal microbiota in growing and weaning pigs, respectively $[136,137]$. More studies are needed to confirm the antimicrobial activity of PUFA in weaning pigs.

\subsection{Organic Acids}

With the existing evidence on the antimicrobial properties of some organic acids through the modulation of microbiota populations and reduction of pathogenic bacteria, organic acids are no longer regarded as simple acidifiers of animal feed, but rather as growth promoters and potential antibiotic substitutes [58-62,138-143]. For instance, lactic acid supplementation stimulated pancreatic secretion of piglets and reduced the incidence of post-weaning diarrhea $[58,138]$. In contrast, the microbiota composition in the gastrointestinal tract of weanling pigs, or the $E$. coli count in post-weaning pigs were not affected by citric acid supplementation $[139,140]$. However, the combination of organic acids $(0.416 \%$ fumaric and $0.328 \%$ lactic acid) and medium-chain fatty acids $(0.15 \%$ capric and caprylic acid) has been demonstrated to modulate gut microbiota and prevent postweaning diarrhea [141]. In another study, Ferrara et al. [142] reported that the organic acid blends $(0.15 \%$ caprylic and capric acids $+0.41 \%$ fumaric acid and $0.32 \%$ lactic acid) with and without MCFA increased the number of intra-epithelial lymphocytes in the jejunum. Ahmed et al. [143] also indicated that supplementation of $0.4 \%$ acidifier blend consisting of $17.2 \%$ formic acid, $4.1 \%$ propionic acid, $10.2 \%$ lactic acid, $9.5 \%$ phosphoric acid, and $\mathrm{SiO}_{2} 34.0 \%$ in the basal diet of weaned piglets led to the reduction in fecal counts of pathogenic gram-negative Salmonella and E. coli and increased beneficial Lactobacilli and Bacilli concentrations compared to the control. Our recently published study investigated the effects of blends of $40 \%$ coated organic acid blends (17\% fumaric acid, $13 \%$ citric acid, 
10\% malic acid), 1.2\% MCFAs (capric and caprylic acids), and 58.8\% vegetable oil carriers on the growth performance of weaning pigs. When this feed supplement was incorporated into the diet at a $0.2 \%$ dose, it led to improvements in growth performance and nutrient digestibility [60].

The antimicrobial properties of organic acids are suggested to be due to their ability to cross the bacterial cell membrane. Organic acids are considered as bioactive compounds when their minimum inhibitory concentration is equal to or lower than $1000 \mathrm{ppm}$ [144]. Organic acids in their undissociated form can modify the proton and associated anion concentrations in the cytoplasm, thereby negatively affecting essential enzymes and purine bases, resulting in the reduction of bacterial viability [145].

Thus, it can be seen that using blends rather than single organic acids, and coated versus non-coated organic acids tended to have wider-ranging action against pathogens in improving gut health and performance. However, some studies did not observe antimicrobial activities of certain organic acid feed additives either in coated or non-coated forms [146-148], suggesting that further studies are needed in order to optimize concentrations, combinations, and interactions of these compounds against target pathogens.

\section{Conclusions}

Weaning is one of the most stressful and complex events in pigs' lives. Among several stressors, the stress of separation of piglets from their dam and abrupt change in the diet of piglets from the liquid to solid diet is quite critical, leading to gut-associated problems and immune functions which may persist until adulthood. The intention of this paper was to review the current knowledge in the literature on the nutritional intervention and the mechanistic aspects of several feed additives such as probiotics, prebiotics, organic acids, plant extracts, short-/medium-chain fatty acid, and polyunsaturated fatty acid in mitigating the impact of weaning stress on the gut health of weaning pigs. Moreover, there are many more candidates of feed additives than the ones listed in this review that are influential in regulating intestinal environments and enhancing weaned pig performance. The mechanistic aspect of different feed additives mentioned in this review in alleviating intestinal dysfunction is basically due to the bacteriostatic or bactericidal properties of these feed additives against the pathogens or due to the change in the expression of certain genes related with tight junctions influencing certain signaling pathways or stimulation of certain gastric cells and enzymes that eventually promote gut health. Based on the published literatures, it can be seen that these feed additives exert positive effects as well as non-significant effects in growth performance and gut health. The reported positive impact of these feed additives indicate that these feed additives can be effectively used to support a profitable and sustainable swine production. However, due consideration must be given to the dose, efficacy, and safety on the usage of these feed additives. The non-detectable positive impact of some of these feed additives could have been influenced by the energy content and protein level in the diets of young pigs and thus consideration should be taken on the diet composition. More research into optimizing these feed additives and the corresponding feeding regimen is suggested.

Author Contributions: Conceptualization, I.-H.K., S.-D.U.; methodology, S.-D.U.; writing-original draft preparation, S.-D.U.; writing-review and editing, I.-H.K. All authors have read and agreed to the published version of the manuscript.

Funding: This study was supported by the research fund of Dankook University in 2021.

Institutional Review Board Statement: Not applicable.

Data Availability Statement: Not applicable.

Conflicts of Interest: The authors declare no conflict of interest. 


\section{References}

1. Li, Y.; Guo, Y.; Wen, Z.; Jiang, X.; Ma, X.; Han, X. Weaning Stress Perturbs Gut Microbiome and Its Metabolic Profile in Piglets. Sci. Rep. 2018, 8, 1-12. [CrossRef]

2. Spreeuwenberg, M.A.M.; Verdonk, J.M.A.J.; Gaskins, H.R.; Verstegen, M.W.A. Small Intestine Epithelial Barrier Function Is Compromised in Pigs with Low Feed Intake at Weaning. J. Nutr. 2001, 131, 1520-1527. [CrossRef]

3. Stokes, C.R.; Bailey, M.; Haverson, K.; Harris, C.; Jones, P.; Inman, C.; Pié, S.; Oswald, I.P.; Williams, B.A.; Akkermans, A.D.; et al. Postnatal development of intestinal immune system in piglets: Implications for the process of weaning. Anim. Res. 2004, 53, 325-334. [CrossRef]

4. Moeser, A.J.; Pohl, C.S.; Rajput, M. Weaning stress and gastrointestinal barrier development: Implications for lifelong gut health in pigs. Anim. Nutr. 2017, 3, 313-321. [CrossRef]

5. Xiong, X.; Tan, B.; Song, M.; Ji, P.; Kim, K.; Yin, Y.; Liu, Y. Nutritional Intervention for the Intestinal Development and Health of Weaned Pigs. Front. Vet. Sci. 2019, 6, 46. [CrossRef]

6. Jayaraman, B.; Nyachoti, C.M. Husbandry practices and gut health outcomes in weaned piglets: A review. Anim. Nutr. 2017, 3, 205-211. [CrossRef] [PubMed]

7. Pácha, J. Development of Intestinal Transport Function in Mammals. Physiol. Rev. 2000, 80, 1633-1667. [CrossRef] [PubMed]

8. Wijtten, P.J.A.; van der Meulen, J.; Verstegen, M.W.A. Intestinal barrier function and absorption in pigs after weaning: A review. Br. J. Nutr. 2011, 105, 967-981. [CrossRef] [PubMed]

9. Pluske, J.R.; Turpin, D.; Kim, J.-C. Gastrointestinal tract (gut) health in the young pig. Anim. Nutr. 2018, 4, 187-196. [CrossRef] [PubMed]

10. Boudry, G.; Péron, V.; Luron, I.; Lallès, J.-P.; Sève, B. Weaning Induces Both Transient and Long-Lasting Modifications of Absorptive, Secretory, and Barrier Properties of Piglet Intestine. J. Nutr. 2004, 134, 2256-2262. [CrossRef] [PubMed]

11. Lallès, J.-P.; Boudry, G.; Favier, C.; Le Floc'H, N.; Luron, I.; Montagne, L.; Oswald, I.; Pié, S.; Piel, C.; Sève, B. Gut function and dysfunction in young pigs: Physiology. Anim. Res. 2004, 53, 301-316. [CrossRef]

12. Lallès, J.-P. Intestinal alkaline phosphatase: Multiple biological roles in maintenance of intestinal homeostasis and modulation by diet. Nutr. Rev. 2010, 68, 323-332. [CrossRef] [PubMed]

13. Hampson, D. Alterations in piglet small intestinal structure at weaning. Res. Vet. Sci. 1986, 40, 32-40. [CrossRef]

14. Madara, J.L. Warner-Lambert/Parke-Davis Award lecture. Pathobiology of the intestinal epithelial barrier. Am. J. Pathol. 1990, $137,1273-1281$.

15. Nabuurs, M.J. Weaning piglets as a model for studying pathophysiology of diarrhea. Vet. Q. 1998, 20, S42-S45. [CrossRef] [PubMed]

16. Henderson, P.; van Limbergen, J.; Schwarze, J.; Wilson, D.C. Function of the intestinal epithelium and its dysregulation in inflammatory bowel disease. Inflamm. Bowel Dis. 2011, 17, 382-395. [CrossRef] [PubMed]

17. Moeser, A.J.; Ryan, K.A.; Nighot, P.K.; Blikslager, A. Gastrointestinal dysfunction induced by early weaning is attenuated by delayed weaning and mast cell blockade in pigs. Am. J. Physiol. Liver Physiol. 2007, 293, G413-G421. [CrossRef] [PubMed]

18. Smith, F.; Clark, J.E.; Overman, B.L.; Tozel, C.C.; Huang, J.H.; Rivier, J.E.F.; Blisklager, A.T.; Moeser, A.J. Early weaning stress impairs development of mucosal barrier function in the porcine intestine. Am. J. Physiol. Liver Physiol. 2010, 298, G352-G363. [CrossRef] [PubMed]

19. Pohl, C.S.; Medland, J.E.; Moeser, A.J. Early life stress origins of gastrointestinal disease: Animal models, intestinal pathophysiology, and translational implications. Am. J. Physiol. Gastrointest. Liver Physiol. 2015, 309, G927-G941. [CrossRef]

20. Medland, J.E.; Pohl, C.S.; Edwards, L.L.; Frandsen, S.; Bagley, K.; Li, Y.; Moeser, A.J. Early life adversity in piglets induces long-term upregulation of the enteric cholinergic nervous system and heightened, sex-specific secretomotor neuron responses. Neurogastroenterol. Motil. 2016, 28, 1317-1329. [CrossRef]

21. Isaacson, R.; Kim, H.B. The intestinal microbiome of the pig. Anim. Health Res. Rev. 2012, 13, 100-109. [CrossRef]

22. Frese, S.A.; Parker, K.; Calvert, C.C.; Mills, D.A. Diet shapes the gut microbiome of pigs during nursing and weaning. Microbiome 2015, 3, 1-10. [CrossRef] [PubMed]

23. Gresse, R.; Chaucheyras-Durand, F.; Fleury, M.A.; van de Wiele, T.; Forano, E.; Blanquet-Diot, S. Gut microbiota dysbiosis in post weaning piglets: Understanding the keys to health. Trends Microbiol. 2017, 25, 851-873. [CrossRef]

24. Yang, Q.; Huang, X.; Zhao, S.; Sun, W.; Yan, Z.; Wang, P.; Li, S.; Huang, W.; Zhang, S.; Liu, L.; et al. Structure and Function of the Fecal Microbiota in Diarrheic Neonatal Piglets. Front. Microbiol. 2017, 8, 502. [CrossRef] [PubMed]

25. Downes, J.; Dewhirst, F.E.; Tanner, A.C.R.; Wade, W.G. Description of Alloprevotella rava gen. nov., sp. nov., isolated from the human oral cavity, and reclassification of Prevotella tannerae Moore et al. 1994 as Alloprevotella tannerae gen. nov., comb. nov. Int. J. Syst. Evol. Microbiol. 2013, 63, 1214-1218. [CrossRef]

26. Konikoff, T.; Gophna, U. Oscillospira: A Central, Enigmatic Component of the Human Gut Microbiota. Trends Microbiol. 2016, 24, 523-524. [CrossRef] [PubMed]

27. Gophna, U.; Konikoff, T.; Nielsen, H.B. Oscillospira and related bacteria-from metagenomic species to metabolic features. Environ. Microbiol. 2017, 19, 835-841. [CrossRef]

28. Xie, Y.; He, Y.; Irwin, P.L.; Jin, T.; Shi, X. Antibacterial Activity and Mechanism of Action of Zinc Oxide Nanoparticles againstCampylobacter jejuni. Appl. Environ. Microbiol. 2011, 77, 2325-2331. [CrossRef] 
29. Kim, H.B.; Borewicz, K.; White, B.A.; Singer, R.S.; Sreevatsan, S.; Tu, Z.J.; Isaacson, R.E. Microbial shifts in the swine distal gut in response to the treatment with antimicrobial growth promoter, tylosin. Proc. Natl. Acad. Sci. USA 2012, 109, 15485-15490. [CrossRef] [PubMed]

30. Hu, J.; Nie, Y.; Chen, J.; Zhang, Y.; Wang, Z.; Fan, Q.; Yan, X. Gradual Changes of Gut Microbiota in Weaned Miniature Piglets. Front. Microbiol. 2016, 7, 1727. [CrossRef]

31. Kim, H.B.; Borewicz, K.; White, B.A.; Singer, R.S.; Sreevatsan, S.; Tu, Z.J.; Isaacson, R.E. Longitudinal investigation of the age-related bacterial diversity in the feces of commercial pigs. Vet. Microbiol. 2011, 153, 124-133. [CrossRef] [PubMed]

32. Pajarillo, E.A.B.; Chae, J.-P.; Balolong, M.P.; Kim, H.B.; Kang, D.-K. Assessment of fecal bacterial diversity among healthy piglets during the weaning transition. J. Gen. Appl. Microbiol. 2014, 60, 140-146. [CrossRef]

33. Guevarra, R.B.; Lee, J.H.; Lee, S.H.; Seok, M.-J.; Kim, D.W.; Na Kang, B.; Johnson, T.J.; Isaacson, R.E.; Kim, H.B. Piglet gut microbial shifts early in life: Causes and effects. J. Anim. Sci. Biotechnol. 2019, 10, 1-10. [CrossRef] [PubMed]

34. Flint, H.J.; Bayer, E.A. Plant Cell Wall Breakdown by Anaerobic Microorganisms from the Mammalian Digestive Tract. Ann. N. Y. Acad. Sci. 2008, 1125, 280-288. [CrossRef] [PubMed]

35. Ivarsson, E.; Roos, S.; Liu, H.; Lindberg, J.E. Fermentable non-starch polysaccharides increases the abundance of BacteroidesPrevotella-Porphyromonas in ileal microbial community of growing pigs. Animal 2014, 8, 1777-1787. [CrossRef] [PubMed]

36. Gänzle, M.G.; Follador, R. Metabolism of Oligosaccharides and Starch in Lactobacilli: A Review. Front. Microbiol. 2012, 3, 340. [CrossRef]

37. McCracken, B.A.; Spurlock, M.E.; Roos, M.A.; Zuckermann, F.A.; Gaskins, H.R. Weaning Anorexia May Contribute to Local Inflammation in the Piglet Small Intestine. J. Nutr. 1999, 129, 613-619. [CrossRef] [PubMed]

38. Pié, S.; Lallès, J.-P.; Blazy, F.; Laffitte, J.; Sève, B.; Oswald, I.P. Weaning Is Associated with an Upregulation of Expression of Inflammatory Cytokines in the Intestine of Piglets. J. Nutr. 2004, 134, 641-647. [CrossRef]

39. Ushida, K.; Kameue, C.; Tsukahara, T.; Fukuta, K.; Nakanishi, N. Decreasing Traits of Fecal Immunoglobulin A in Neonatal and Weaning Piglets. J. Vet. Med Sci. 2008, 70, 849-852. [CrossRef]

40. Ponta, H.; Cato, A.; Herrlich, P. Interference of pathway specific transcription factors. Biochim. Biophys. Acta Gene Struct. Expr. 1992, 1129, 255-261. [CrossRef]

41. Rao, R. Oxidative stress-induced disruption of epithelial and endothelial tight junctions. Front. Biosci. 2008, 13, 7210-7226. [CrossRef] [PubMed]

42. Vergauwen, H.; Tambuyzer, B.; Jennes, K.; DeGroote, J.; Wang, W.; de Smet, S.; Michiels, J.; Van Ginneken, C. Trolox and Ascorbic Acid Reduce Direct and Indirect Oxidative Stress in the IPEC-J2 Cells, an In Vitro Model for the Porcine Gastrointestinal Tract. PLoS ONE 2015, 10, e0120485. [CrossRef] [PubMed]

43. Campbell, J.M.; Crenshaw, J.D.; Polo, J. The biological stress of early weaned piglets. J. Anim. Sci. Biotechnol. 2013, 4, 19. [CrossRef]

44. Dividich, J.L.; Sève, B. Effects of underfeeding during the weaning period on growth, metabolism, and hormonal adjustments in the piglet. Domest. Anim. Endocrinol. 2000, 19, 63-74. [CrossRef]

45. Colson, V.; Orgeur, P.; Foury, A.; Mormède, P. Consequences of weaning piglets at 21 and 28 days on growth, behaviour and hormonal responses. Appl. Anim. Behav. Sci. 2006, 98, 70-88. [CrossRef]

46. Heo, J.M.; Opapeju, F.O.; Pluske, J.R.; Kim, J.C.; Hampson, D.J.; Nyachoti, C.M. Gastrointestinal health and function in weaned pigs: A review of feeding strategies to control post-weaning diarrhea without using in-feed antimicrobial compounds. J. Anim. Physiol. Anim. Nutr. 2013, 97, 207-237. [CrossRef]

47. Kats, L.J.; Tokach, M.D.; Goodband, R.D.; Nelssen, J.L. Influence of weaning weight and growth during the first week postweaning on subsequent pig performance. Kans. Agric. Exp. Stn. Res. Rep. 1992, 15-17. [CrossRef]

48. Lallès, J.; Bosi, P.; Janczyk, P.; Koopmans, S.; Torrallardona, D. Impact of bioactive substances on the gastrointestinal tract and performance of weaned piglets: A review. Animal 2009, 3, 1625-1643. [CrossRef]

49. Pluske, J.R. Feed and feed additives-related aspects of gut health and development in weanling pigs. J. Anim. Sci. Biotechnol. 2013, 4, 1. [CrossRef]

50. Liu, Y.; Espinosa, C.D.; Abelilla, J.J.; Casas, G.A.; Lagos, L.V.; Lee, S.A.; Kwon, W.B.; Mathai, J.K.; Navarro, D.M.D.; Jaworski, N.W.; et al. Non-antibiotic feed additives in diets for pigs: A review. Anim. Nutr. 2018, 4, 113-125. [CrossRef]

51. Ziegler, A.; Gonzalez, L.; Blikslager, A. Large Animal Models: The Key to Translational Discovery in Digestive Disease Research. Cell. Mol. Gastroenterol. Hepatol. 2016, 2, 716-724. [CrossRef] [PubMed]

52. Pang, X.; Hua, X.; Yang, Q.; Ding, D.; Che, C.; Cui, L.; Jia, W.; Bucheli, P.; Zhao, L. Inter-species transplantation of gut microbiota from human to pigs. ISME J. 2007, 1, 156-162. [CrossRef] [PubMed]

53. Hanczakowska, E.; Szewczyk, A.; Okoń, K. Effects of dietary caprylic and capric acids on piglet performance and mucosal epithelium structure of the ileum. J. Anim. Feed. Sci. 2011, 20, 556-565. [CrossRef]

54. Zhang, J.Y.; Hu, J.; Kim, I.H. Supplemental effects of coated omega-3 polyunsaturated fatty acids to basal diet on improving growth performance, nutrients digestibility, fecal lactobacillus count and fecal score in weaning pigs. Anim. Feed. Sci. Technol. 2020, 269, 114547. [CrossRef]

55. Jang, K.B.; Kim, S.W. Supplemental effects of dietary nucleotides on intestinal health and growth performance of newly weaned pigs. J. Anim. Sci. 2019, 97, 4875-4882. [CrossRef] [PubMed]

56. Li, G.; Xie, C.; Wang, Q.; Wan, D.; Zhang, Y.; Wu, X.; Yin, Y. Uridine/UMP metabolism and their function on the gut in segregated early weaned piglets. Food Funct. 2019, 10, 4081-4089. [CrossRef] 
57. Perricone, V.; Comi, M.; Bontempo, V.; Lecchi, C.; Ceciliani, F.; Crestani, M.; Ferrari, A.; Savoini, G.; Agazzi, A. Effects of nucleotides administration on growth performance and immune response of post-weaning piglets. Ital. J. Anim. Sci. 2020, 19, 295-301. [CrossRef]

58. Tsiloyiannis, V.; Kyriakis, S.; Vlemmas, J.; Sarris, K. The effect of organic acids on the control of porcine post-weaning diarrhoea. Res. Vet. Sci. 2001, 70, 287-293. [CrossRef]

59. Luise, D.; Motta, V.; Salvarani, C.; Chiappelli, M.; Fusco, L.; Bertocchi, M.; Mazzoni, M.; Maiorano, G.; Costa, L.N.; van Milgen, J.; et al. Long-term administration of formic acid to weaners: Influence on intestinal microbiota, immunity parameters and growth performance. Anim. Feed. Sci. Technol. 2017, 232, 160-168. [CrossRef]

60. Upadhaya, S.D.; Lee, K.Y.; Serpunja, S.; Song, T.H.; Kim, I.H. Growth performance, nutrient digestibility, fecal microbiota and fecal noxious gas emission in weaning pigs fed high and low density diet with and without protected organic acid blends. Anim. Feed. Sci. Technol. 2018, 239, 1-8. [CrossRef]

61. Long, S.; Xu, Y.; Pan, L.; Wang, Q.; Wang, C.; Wu, J.; Wu, Y.; Han, Y.; Yun, C.; Piao, X. Mixed organic acids as antibiotic substitutes improve performance, serum immunity, intestinal morphology and microbiota for weaned piglets. Anim. Feed. Sci. Technol. 2018, 235, 23-32. [CrossRef]

62. Yang, Y.; Lee, K.Y.; Kim, I. Effects of dietary protected organic acids on growth performance, nutrient digestibility, fecal microflora, diarrhea score, and fecal gas emission in weanling pigs. Can. J. Anim. Sci. 2019, 99, 514-520. [CrossRef]

63. Xu, C.; Chen, X.; Ji, C.; Ma, Q.; Hao, K. Study of the application of fructo-oligosaccharides in piglets. Asian-Australas. J. Anim. Sci. 2005, 18, 1011-1016. [CrossRef]

64. Bhandari, S.K.; Nyachoti, C.M.; Krause, D.O. Raw potato starch in weaned pig diets and its influence on post-weaning scours and the molecular microbial ecology of the digestive tract. J. Anim. Sci. 2009, 87, 984-993. [CrossRef]

65. Patterson, J.K.; Yasuda, K.; Welch, R.M.; Miller, D.D.; Lei, X.G. Supplemental Dietary Inulin of Variable Chain Lengths Alters Intestinal Bacterial Populations in Young Pigs. J. Nutr. 2010, 140, 2158-2161. [CrossRef] [PubMed]

66. Guerra-Ordaz, A.A.; González-Ortiz, G.; La Ragione, R.M.; Woodward, M.J.; Collins, J.W.; Pérez, J.F.; Martín-Orúe, S.M. Lactulose and Lactobacillus plantarum, a Potential Complementary Synbiotic To Control Postweaning Colibacillosis in Piglets. Appl. Environ. Microbiol. 2014, 80, 4879-4886. [CrossRef]

67. Lei, X.J.; Kim, Y.M.; Park, J.H.; Baek, D.H.; Nyachoti, C.M.; Kim, I.H. Effects of levan-type fructan on growth performance, nutrient digestibility, diarrhoea scores, faecal shedding of total lactic acid bacteria and coliform bacteria, and faecal gas emission in weaning pigs. J. Sci. Food Agric. 2017, 98, 1539-1544. [CrossRef] [PubMed]

68. Xing, Y.-Y.; Li, K.-N.; Xu, Y.-Q.; Wu, Y.-Z.; Shi, L.-L.; Guo, S.-W.; Yan, S.-M.; Jin, X.; Shi, B.-L. Effects of galacto-oligosaccharide on growth performance, feacal microbiota, immune response and antioxidant capability in weaned piglets. J. Appl. Anim. Res. 2020, 48, 63-69. [CrossRef]

69. Van der Peet-Schwering, C.M.C.; Jansman, A.J.M.; Smidt, H.; Yoon, I. Effects of yeast culture on performance, gut integrity, and blood cell composition of weanling pigs 1,2. J. Anim. Sci. 2007, 85, 3099-3109. [CrossRef]

70. Konstantinov, S.R.; Smidt, H.; Akkermans, A.D.L.; Casini, L.; Treisi, P.; Mazzoni, M.; Filippi, S.D.; Bosi, P.; De vos, W.M. Feeding of Lactobacillus sobrius reduces Escherichia coli F4 levels in the gut and promotes growth of infected piglets. FEMS Microbiol. Ecol. 2008, 66, 599-607. [CrossRef]

71. Shen, Y.B.; Piao, X.S.; Kim, S.W.; Wang, L.; Liu, P.; Yoon, I.; Zhen, Y.G. Effects of yeast culture supplementation on growth performance, intestinal health, and immune response of nursery pigs1. J. Anim. Sci. 2009, 87, 2614-2624. [CrossRef]

72. Chiang, M.-L.; Chen, H.-C.; Chen, K.-N.; Lin, Y.-C.; Lin, Y.-T.; Chen, M.-J. Optimizing Production of Two Potential Probiotic Lactobacilli Strains Isolated from Piglet Feces as Feed Additives for Weaned Piglets. Asian-Australas. J. Anim. Sci. 2015, 28, 1163-1170. [CrossRef]

73. Hu, Y.; Dun, Y.; Li, S.; Zhang, D.; Peng, N.; Zhao, S.; Liang, Y. Dietary Enterococcus faecalis LAB31 Improves Growth Performance, Reduces Diarrhea, and Increases Fecal Lactobacillus Number of Weaned Piglets. PLoS ONE 2015, 10, e0116635. [CrossRef]

74. Wang, H.; Kim, K.P.; Kim, I.H. Influence of Bacillus subtilis GCB-13-001 on growth performance, nutrient digestibility, blood characteristics, faecal microbiota and faecal score in weanling pigs. J. Anim. Physiol. Anim. Nutr. 2019, 103, 1919-1925. [CrossRef] [PubMed]

75. Nguyen, D.H.; Nyachoti, C.M.; Kim, I.H. Evaluation of effect of probiotics mixture supplementation on growth performance, nutrient digestibility, faecal bacterial enumeration, and noxious gas emission in weaning pigs. Ital. J. Anim. Sci. 2018, 18, 466-473. [CrossRef]

76. He, Y.; Jinno, C.; Kim, K.; Wu, Z.; Tan, B.; Li, X.; Whelan, R.; Liu, Y. Dietary Bacillus spp. enhanced growth and disease resistance of weaned pigs by modulating intestinal microbiota and systemic immunity. J. Anim. Sci. Biotechnol. 2020, 11, 1-19. [CrossRef] [PubMed]

77. Yan, L.; Meng, Q.W.; Kim, I.H. Effect of an herb extract mixture on growth performance, nutrient digestibility, blood characteristics, and fecal microbial shedding in weanling pigs. Livest. Sci. 2012, 145, 189-195. [CrossRef]

78. Bontempo, V.; Jiang, X.-R.; Cheli, F.; Verso, L.L.; Mantovani, G.; Vitari, F.; Domeneghini, C.; Agazzi, A. Administration of a novel plant extract product via drinking water to post-weaning piglets: Effects on performance and gut health. Animal 2014, 8, 721-730. [CrossRef] [PubMed]

79. Lee, S.I.; Kim, I.H. Eckol Alleviates Intestinal Dysfunction during Suckling-to-Weaning Transition via Modulation of PDX1 and HBEGF. Int. J. Mol. Sci. 2020, 21, 4755. [CrossRef] 
80. Cosgrove, M. Perinatal and infant nutrition. Nucleotides. Nutrition 1998, 14, 748-751. [CrossRef]

81. Sauer, N.; Mosenthin, R.; Bauer, E. The role of dietary nucleotides in single-stomached animals. Nutr. Res. Rev. 2011, 24, 46-59. [CrossRef] [PubMed]

82. Che, L.; Hu, L.; Liu, Y.; Yan, C.; Peng, X.; Xu, Q.; Wang, R.; Cheng, Y.; Chen, H.; Fang, Z.; et al. Dietary Nucleotides Supplementation Improves the Intestinal Development and Immune Function of Neonates with Intra-Uterine Growth Restriction in a Pig Model. PLoS ONE 2016, 11, e0157314. [CrossRef] [PubMed]

83. Stein, H.H.; Mateo, C.D. Nucleotides may have a role in nutrition of young pigs. Feedstuffs 2004, 76, 11-14.

84. Superchi, P.; Saleri, R.; Borghetti, P.; de Angelis, E.; Ferrari, L.; Cavalli, V.; Amicucci, P.; Ossiprandi, M.C.; Sabbioni, A. Effects of dietary nucleotide supplementation on growth performance and hormonal and immune responses of piglets. Animal 2012, 6, 902-908. [CrossRef] [PubMed]

85. Li, H.; Zhao, P.; Lei, Y.; Li, T.; Kim, I. Response to an Escherichia coli K88 oral challenge and productivity of weanling pigs receiving a dietary nucleotides supplement. J. Anim. Sci. Biotechnol. 2015, 6, 49. [CrossRef]

86. Waititu, S.M.; Yin, F.; Patterson, R.; Yitbarek, A.; Rodriguez-Lecompte, J.C.; Nyachoti, C.M. Dietary supplementation with a nucleotide-rich yeast extract modulates gut immune response and microflora in weaned pigs in response to a sanitary challenge. Animal 2017, 11, 2156-2164. [CrossRef]

87. Kulkarni, A.D.; Rudolph, F.B.; van Buren, C.T. The Role of Dietary Sources of Nucleotides in Immune Function: A Review. J. Nutr. 1994, 124, 1442S-1446S. [CrossRef]

88. Mateo, C.D.; Peters, D.N.; Stein, H.H. Nucleotides in sow colostrum and milk at different stages of lactation 1,2,3. J. Anim. Sci. 2004, 82, 1339-1342. [CrossRef] [PubMed]

89. Lee, S.I.; Kim, I.H. Nucleotide-mediated SPDEF modulates TFF3-mediated wound healing and intestinal barrier function during the weaning process. Sci. Rep. 2018, 8, 1-13. [CrossRef]

90. Sauer, N.; Eklund, M.; Bauer, E.; Gänzle, M.; Field, C.; Zijlstra, R.T.; Mosenthin, R. The effects of pure nucleotides on performance, humoral immunity, gut structure and numbers of intestinal bacteria of newly weaned pigs1. J. Anim. Sci. 2012, 90, 3126-3134. [CrossRef] [PubMed]

91. Upadhaya, S.D.; Kim, I.H. Efficacy of phytogenic feed additive on performance, production and health status of monogastric animals-a review. Ann. Anim. Sci. 2017, 17, 929-948. [CrossRef]

92. Lillehoj, H.; Liu, Y.; Calsamiglia, S.; Fernandez-Miyakawa, M.E.; Chi, F.; Cravens, R.L.; Oh, S.; Gay, C.G. Phytochemicals as potential antibiotic alternatives to promote growth and enhance host health: A report from the second international symposium on alternatives to antibiotics. Vet. Res. 2018, 46, 76-93. [CrossRef] [PubMed]

93. Liu, Y.; Song, M.; Che, T.M.; Almeida, J.A.S.; Lee, J.J.; Bravo, D.; Maddox, C.W.; Pettigrew, J.E. Dietary plant extracts alleviate diarrhea and alter immune responses of weaned pigs experimentally infected with a pathogenic Escherichia coli1. J. Anim. Sci. 2013, 91, 5294-5306. [CrossRef] [PubMed]

94. Zou, Y.; Xiang, Q.; Wang, J.; Peng, J.; Wei, H. Oregano Essential Oil Improves Intestinal Morphology and Expression of Tight Junction Proteins Associated with Modulation of Selected Intestinal Bacteria and Immune Status in a Pig Model. Bio. Med. Res. Int. 2016, 2016, 1-11. [CrossRef]

95. Yuan, D.; Hussain, T.; Tan, B.; Liu, Y.; Ji, P.; Yin, Y. The Evaluation of Antioxidant and Anti-Inflammatory Effects ofEucommia ulmoidesFlavones Using Diquat-Challenged Piglet Models. Oxidative Med. Cell. Longev. 2017, 2017, 1-9. [CrossRef]

96. Choi, Y.; Hosseindoust, A.; Goel, A.; Lee, S.; Jha, P.K.; Kwon, I.K.; Chae, B.-J. Effects of Ecklonia cava as fucoidan-rich algae on growth performance, nutrient digestibility, intestinal morphology and caecal microflora in weanling pigs. Asian-Australas. J. Anim. Sci. 2016, 30, 64-70. [CrossRef] [PubMed]

97. Boirivant, M.; Strober, W. The mechanism of action of probiotics. Curr. Opin. Gastroenterol. 2007, 23, 679-692. [CrossRef]

98. De Vrese, M.; Schrezenmeir, J. Probiotics, prebiotics, synbiotics. Adv. Biochem. Eng. Biotechnol. 2008, 111, 1-66.

99. Upadhaya, S.D.; Shanmugam, S.K.; Kang, D.K.; Kim, I.H. Preliminary assessment on potentials of probiotic B. subtilis RX7 and B. methylotrophicus C14 strains as an immune modulator in Salmonella-challenged weaned pigs. Trop. Anim. Health Prod. 2017, 49, 1065-1070. [CrossRef]

100. Ohland, C.L.; Macnaughton, W.K. Probiotic bacteria and intestinal epithelial barrier function. Am. J. Physiol. Liver Physiol. 2010, 298, G807-G819. [CrossRef]

101. Rose, E.; Odle, J.; Blikslager, A.; Ziegler, A. Probiotics, Prebiotics and Epithelial Tight Junctions: A Promising Approach to Modulate Intestinal Barrier Function. Int. J. Mol. Sci. 2021, 22, 6729. [CrossRef] [PubMed]

102. Huan-Long, Q.; Shen, T.Y.; Gao, Z.G.; Fan, X.B.; Hang, X.M.; Jiang, Y.Q.; Zhang, H.Z. Effect of lactobacillus on the gut microflora and barrier function of the rats with abdominal infection. World J. Gastroenterol. 2005, 11, 2591.

103. Anderson, R.C.; Cookson, A.L.; McNabb, W.C.; Park, Z.; McCann, M.J.; Kelly, W.J.; Roy, N.C. Lactobacillus plantarum MB452 enhances the function of the intestinal barrier by increasing the expression levels of genes involved in tight junction formation. BMC Microbiol. 2010, 10, 316. [CrossRef] [PubMed]

104. Karczewski, J.; Troost, F.J.; Konings, I.; Dekker, J.; Kleerebezem, M.; Brummer, R.-J.M.; Wells, J.M. Regulation of human epithelial tight junction proteins by Lactobacillus plantarum in vivo and protective effects on the epithelial barrier. Am. J. Physiol. Liver Physiol. 2010, 298, G851-G859. [CrossRef] [PubMed] 
105. Blackwood, B.P.; Yuan, C.Y.; Wood, D.R.; Nicolas, J.D.; Grothaus, J.S.; Hunter, C.J. Probiotic Lactobacillus Species Strengthen Intestinal Barrier Function and Tight Junction Integrity in Experimental Necrotizing Enterocolitis. J. Probiotics Health 2017, 5. [CrossRef] [PubMed]

106. Bergmann, K.R.; Liu, S.X.; Tian, R.; Kushnir, A.; Turner, J.R.; Li, H.-L.; Chou, P.M.; Weber, C.; De Plaen, I.G. Bifidobacteria Stabilize Claudins at Tight Junctions and Prevent Intestinal Barrier Dysfunction in Mouse Necrotizing Enterocolitis. Am. J. Pathol. 2013, 182, 1595-1606. [CrossRef]

107. Mattar, A.F.; Teitelbaum, D.H.; Drongowski, R.A.; Yongyi, F.; Harmon, C.M.; Coran, A.G. Probiotics up-regulate MUC-2 mucin gene expression in a Caco-2 cell-culture model. Pediatr. Surg. Int. 2002, 18, 586-590.

108. Mack, D.R.; Ahrne, S.; Hyde, L.; Wei, S.; Hollingsworth, M.A. Extracellular MUC3 mucin secretion follows adherence of Lactobacillus strains to intestinal epithelial cells in vitro. Gut 2003, 52, 827-833. [CrossRef]

109. Shanahan, F. A commentary on the safety of probiotics. Gastroenterol. Clin. North Am. 2012, 41, 869-876. [CrossRef]

110. Gibson, G.R.; Roberfroid, M.B. Dietary Modulation of the Human Colonic Microbiota: Introducing the Concept of Prebiotics. J. Nutr. 1995, 125, 1401-1412. [CrossRef]

111. Chen, Q.; Ren, Y.; Lu, J.; Bartlett, M.; Chen, L.; Zhang, Y.; Guo, X.; Liu, C. A Novel Prebiotic Blend Product Prevents Irritable Bowel Syndrome in Mice by Improving Gut Microbiota and Modulating Immune Response. Nutrients 2017, 9, 1341. [CrossRef] [PubMed]

112. Wang, J.; Tian, S.; Yu, H.; Wang, J.; Zhu, W. Response of colonic mucosa-associated microbiota composition, mucosal immune homeostasis, and barrier function to early life galacto-oligosaccharides intervention in suckling piglets. J. Agric. Food Chem. 2019, 67, 578-588. [CrossRef] [PubMed]

113. Wang, G.; Sun, W.; Pei, X.; Jin, Y.; Wang, H.; Tao, W.; Xiao, Z.; Liu, L.; Wang, M. Galactooligosaccharide pretreatment alleviates damage of the intestinal barrier and inflammatory responses in LPS-challenged mice. Food Funct. 2021, 12, 1569-1579. [CrossRef] [PubMed]

114. Uerlings, J.; Schroyen, M.; Willems, E.; Tanghe, S.; Bruggeman, G.; Bindelle, J.; Everaert, N. Differential effects of inulin or its fermentation metabolites on gut barrier and immune function of porcine intestinal epithelial cells. J. Funct. Foods 2020, 67, 103855. [CrossRef]

115. Peng, L.; Li, Z.-R.; Green, R.S.; Holzman, I.R.; Lin, J. Butyrate Enhances the Intestinal Barrier by Facilitating Tight Junction Assembly via Activation of AMP-Activated Protein Kinase in Caco-2 Cell Monolayers. J. Nutr. 2009, 139, 1619-1625. [CrossRef]

116. Wongkrasant, P.; Pongkorpsakol, P.; Ariyadamrongkwan, J.; Meesomboon, R.; Satitsri, S.; Pichyangkura, R.; Barrett, K.E.; Muanprasat, C. A prebiotic fructo-oligosaccharide promotes tight junction assembly in intestinal epithelial cells via an AMPKdependent pathway. Biomed. Pharmacother. 2020, 129, 110415. [CrossRef]

117. Muanprasat, C.; Wongkrasant, P.; Satitsri, S.; Moonwiriyakit, A.; Pongkorpsakol, P.; Mattaveewong, T.; Pichyangkura, R.; Chatsudthipong, V. Activation of AMPK by chitosan oligosaccharide in intestinal epithelial cells: Mechanism of action and potential applications in intestinal disorders. Biochem. Pharmacol. 2015, 96, 225-236. [CrossRef]

118. Biagi, G.; Piva, A.; Moschini, M.; Vezzali, E.; Roth, F.X. Performance, intestinal microflora, and wall morphology of weanling pigs fed sodium butyrate1. J. Anim. Sci. 2007, 85, 1184-1191. [CrossRef]

119. Mazzoni, M.; Gall, M.L.; de Filippi, S.; Minieri, L.; Trevisi, P.; Woliński, J.; Lalatta-Costerbosa, G.; Lallès, J.-P.; Guilloteau, P.; Bosi, P. Supplemental Sodium Butyrate Stimulates Different Gastric Cells in Weaned Pigs. J. Nutr. 2008, 138, 1426-1431. [CrossRef] [PubMed]

120. Gall, M.L.; Gallois, M.; Sève, B.; Louveau, I.; Holst, J.J.; Oswald, I.; Lallès, J.-P.; Guilloteau, P. Comparative effect of orally administered sodium butyrate before or after weaning on growth and several indices of gastrointestinal biology of piglets. $\mathrm{Br}$. $\mathrm{J}$. Nutr. 2009, 102, 1285-1296. [CrossRef] [PubMed]

121. Upadhaya, S.D.; Jiao, Y.; Kim, Y.M.; Lee, K.Y.; Kim, I.H.; Yang, J. Coated sodium butyrate supplementation to a reduced nutrient diet enhanced the performance and positively impacted villus height and faecal and digesta bacterial composition in weaner pigs. Anim. Feed. Sci. Technol. 2020, 265, 114534. [CrossRef]

122. Deschepper, K.; Gantois, I.; Maertens, L.; van Meenen, E. A balanced mixture of medium chain fatty acids improves zootechnical performances and slaughter results of broilers. In Proceedings of the International Poultry Scientific Forum, Atlanta, GA, USA, 28-29 January 2013; p. 22.

123. Jackman, J.A.; Boyd, R.D.; Elrod, C.C. Medium-chain fatty acids and monoglycerides as feed additives for pig production: Towards gut health improvement and feed pathogen mitigation. J. Anim. Sci. Biotechnol. 2020, 11, 1-15. [CrossRef]

124. Yoon, B.K.; Jackman, J.A.; Valle-González, E.R.; Cho, N.-J. Antibacterial Free Fatty Acids and Monoglycerides: Biological Activities, Experimental Testing, and Therapeutic Applications. Int. J. Mol. Sci. 2018, 19, 1114. [CrossRef]

125. Skřivanová, E.; Marounek, M.; Benda, V.; Březina, P. Susceptibility of Escherichia coli, Salmonella sp and Clostridium perfringens to organic acids and monolaurin. Vet. Med. 2006, 51, 81-88. [CrossRef]

126. Hong, S.M.; Hwang, J.H.; Kim, I.H. Effect of Medium-chain Triglyceride (MCT) on Growth Performance, Nutrient Digestibility, Blood Characteristics in Weanling Pigs. Asian-Australas. J. Anim. Sci. 2012, 25, 1003-1008. [CrossRef] [PubMed]

127. Li, Y.; Zhang, H.; Yang, L.; Zhang, L.; Wang, T. Effect of medium-chain triglycerides on growth performance, nutrient digestibility, plasma metabolites and antioxidant capacity in weanling pigs. Anim. Nutr. 2015, 1, 12-18. [CrossRef]

128. Lee, S.I.; Kang, K.S. Function of capric acid in cyclophosphamide-induced intestinal inflammation, oxidative stress, and barrier function in pigs. Sci. Rep. 2017, 7, 1-12. [CrossRef] 
129. Wang, J.; Huang, N.; Xiong, J.; Wei, H.; Jiang, S.; Peng, J. Caprylic acid and nonanoic acid upregulate endogenous host defense peptides to enhance intestinal epithelial immunological barrier function via histone deacetylase inhibition. Int. Immunopharmacol. 2018, 65, 303-311. [CrossRef]

130. Zhou, Z.; Huang, J.; Hao, H.; Wei, H.; Zhou, Y.; Peng, J. Applications of new functions for inducing host defense peptides and synergy sterilization of medium chain fatty acids in substituting in-feed antibiotics. J. Funct. Foods 2018, 52, 348-359. [CrossRef]

131. Desbois, A.; Smith, V.J. Antibacterial free fatty acids: Activities, mechanisms of action and biotechnological potential. Appl. Microbiol. Biotechnol. 2009, 85, 1629-1642. [CrossRef]

132. Desbois, A.P. Potential Applications of Antimicrobial Fatty Acids in Medicine, Agriculture and Other Industries. Recent Pat. Anti-Infect. Drug Discov. 2012, 7, 111-122. [CrossRef]

133. Desbois, A.P.; Lawlor, K.C. Antibacterial Activity of Long-Chain Polyunsaturated Fatty Acids against Propionibacterium acnes and Staphylococcus aureus. Mar. Drugs 2013, 11, 4544-4557. [CrossRef]

134. Wieckowski, M.; Wojtczak, L. Fatty acid-induced uncoupling of oxidative phosphorylation is partly due to opening of the mitochondrial permeability transition pore. FEBS Lett. 1998, 423, 339-342. [CrossRef]

135. Shaikh, S.R.; Jolly, C.A.; Chapkin, R. n-3 Polyunsaturated fatty acids exert immunomodulatory effects on lymphocytes by targeting plasma membrane molecular organization. Mol. Asp. Med. 2012, 33, 46-54. [CrossRef]

136. Holman, D.B.; Baurhoo, B.; Chénier, M.R. Temporal analysis of the effect of extruded flaxseed on the swine gut microbiota. Can. J. Microbiol. 2014, 60, 649-659. [CrossRef] [PubMed]

137. Upadhaya, S.D.; Kim, I.H. Supplemental effects of fish oil and powdered/coated docosahexaenoic acid on the growth performance, nutrient digestibility, blood profile and fecal coliform and lactic acid bacteria counts in weaner pigs. Anim. Feed. Sci. Technol. 2021, 275, 114885. [CrossRef]

138. Thaela, M.-J.; Jensen, M.S.; Pierzynowski, S.G.; Jakob, S. Effect of lactic acid supplementation on pancreatic secretion in pigs after weaning. J. Anim. Feed. Sci. 1998, 7, 181-183. [CrossRef]

139. Risley, C.R.; Kornegay, E.T.; Lindemann, M.D.; Wood, C.M.; Eigel, W.N. Effect of feeding organic acids on gastrointestinal digesta measurements at various times postweaning in pigs challenged with enterotoxigenic Escherichia coli. Can. J. Anim. Sci. 1993, 73, 931-940. [CrossRef]

140. Risley, C.; Kornegay, E.; Lindemann, M.; Weakland, S. Effects of organic acids with and without a microbial culture on performance and gastrointestinal tract measurements of weanling pigs. Anim. Feed. Sci. Technol. 1991, 35, 259-270. [CrossRef]

141. Zentek, J.; Ferrara, F.; Pieper, R.; Tedin, L.; Meyer, W.; Vahjen, W. Effects of dietary combinations of organic acids and medium chain fatty acids on the gastrointestinal microbial ecology and bacterial metabolites in the digestive tract of weaning piglets. $J$. Anim. Sci. 2013, 91, 3200-3210. [CrossRef]

142. Ferrara, F.; Tedin, L.; Pieper, R.; Meyer, W.; Zentek, J. Influence of medium-chain fatty acids and short-chain organic acids on jejunal morphology and intra-epithelial immune cells in weaned piglets. J. Anim. Physiol. Anim. Nutr. 2016, 101, 531-540. [CrossRef] [PubMed]

143. Ahmed, S.T.; Hwang, J.A.; Hoon, J.; Mun, H.S.; Yang, C.J. Comparison of single and blend of acidifiers as an alternative to antibiotics on growth performance, fecal microflora and humoral immunity in weaned piglets. Asian-Australas. J. Anim. Sci. 2014, 27, 93-100. [CrossRef] [PubMed]

144. Popiolek, L.; Biernasiuk, A. Design, synthesis, and in vitro antimicrobial activity of hydrazide-hydrazones of 2-substituted acetic acid. Chem. Biol. Drug Des. 2016, 88, 873-883. [CrossRef] [PubMed]

145. Warnecke, T.; Gill, R.T. Organic acid toxicity, tolerance, and production in Escherichia coli biorefining applications. Microb. Cell Factories 2005, 4, 25. [CrossRef] [PubMed]

146. Lynch, H.; Leonard, F.; Walia, K.; Lawlor, P.; Duffy, G.; Fanning, S.; Markey, B.; Brady, C.; Gardiner, G.; Argüello, H. Investigation of in-feed organic acids as a low cost strategy to combat Salmonella in grower pigs. Prev. Vet. Med. 2017, 139, 50-57. [CrossRef]

147. Walia, K.; Argüello, H.; Lynch, H.; Leonard, F.C.; Grant, J.; Yearsley, D.; Kelly, S.; Duffy, G.; Gardiner, G.E.; Lawlor, P.G. Effect of strategic administration of an encapsulated blend of formic acid, citric acid, and essential oils on Salmonella carriage, seroprevalence, and growth of finishing pigs. Prev. Vet. Med. 2017, 137, 28-35. [CrossRef]

148. Koyuncu, S.; Andersson, M.G.; Löfström, C.; Skandamis, P.N.; Gounadaki, A.; Zentek, J.; Häggblom, P. Organic acids for control of Salmonella in different feed materials. BMC Vet. Res. 2013, 9, 81. [CrossRef] [PubMed] 